\title{
The Potential Pyrophoricity of BMI-SPEC and Aluminum Plate Spent Fuels Retrieved From Underwater Storage
}

\begin{abstract}
M. A. Ebner
Idaho National Engineering Laboratory

Lockheed Martin Idaho Technologies Co.
\end{abstract}

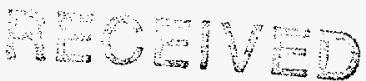

A46 221930

OSTI

Summary

The physical and chemical factors pertaining to uranium metal and uranium hydride combustion, and particularly pyrophoricity in an ambient environment, have been evaluated for the BMI-SPEC and the $\mathrm{UAl}_{\mathrm{x}}$ plate fuels. Some metal fuels may have a highly reactive chemical and physical configuration, such as a high specific surface area, high decay heat, or a high uranium hydride content resulting from corrosion of the metal during underwater storage, that may cause the spontaneous ignition of the metal fuel in air at ambient (or process) temperatures. However, for the BMI-SPEC and the aluminum plate fuels these characteristics are too low to present a realistic threat of uncontrolled spontaneous combustion at ambient conditions. In particular, while residual uranium hydride is expected to be present in these corroded fuels, the hydride levels are expected to be too low and the configuration too unfavorable to ignite the fuel meat when the fuels are retrieved from the basin and dried. Furthermore, the composition and the microstructure of the UAl fuels further mitigate that risk.

\section{Introduction}

The potential pyrophoricity of corroded fuel has become a concern in the DOE spent fuel management community. The spontaneous uncontrolled combustion of corroded fuel presents thermal and radiological risks to facilities, the environment, and workers by uncontrolled release of radionuclides (spread of contamination) and thermal damage to equipment and facilities.

The risk of pyrophoricity of corroded spent nuclear fuel is currently a concern to the CPP-603 South Basin Fuels Relocation effort. Potentially heavily corroded uranium metal or metal alloy fuels, such as BMI-SPEC and the aluminum plate fuels, have been identified for relocation (see Table 1 of letter KMW-10-94 ${ }^{1}$ ).

The concern over the potential pyrophoricity of corroded spent nuclear fuel pertains only to corroded metal and metal alloy fuels, for uranium metal, among other metals used in nuclear applications, is known to be pyrophoric under conditions of high surface area (i.e., metal shavings, metal powder, or porous metal) or high temperature. In particular, the current concern stems from the possibility that the uncontrolled oxidation of any residual uranium hydride produced by corrosion of the spent fuel might serve as the 'match head' that might ignite the rest of the metal, especially if the metal has a high surface area because of its manufactured configuration, swelling from irradiation damage, , or surface roughening from corrosion. The risk of pyrophoricity pertains only to the retrieval of the spent fuel from underwater storage and in subsequent handling and drying in air since combustion will occur only in an oxygen-rich environment, not under water.

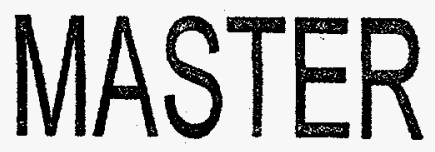


The concern stems from incidents of the spontaneous ignition and combustion of corroded spent nuclear fuel, $, 3,4,5$ and publications that reported the formation of pyrophoric uranium hydride as a reactive byproduct of uranium metal corrosion..$^{6,7,8,9}$ Some literature reported the production of significant concentrations of residual uranium hydride in laboratory corrosion of uranium metal, ranging from 1 to $40 \%$ of hydride in the corrosion product. ${ }^{6,9,10,11,12}$ In addition, BNFL has stated the following concerning proposed relocation of basin-stored metal fuels to dry storage : ${ }^{2}$

"Because of the experience accumulated by BNFL of handling corroded uranium metal fuel the DOE proposal to retrieve, dry and dry store this fuel cannot be recommended. ... The possibility of the dry storage of Magnox fuel after periods of pond storage was independently assessed by the Radioactive Waste Management Advisory Committee (RWMAC). It was concluded that dry storage could not be recommended (due to considerations of the effects of corrosion) and that the reprocessing of this fuel was the technically correct option."

Furthermore, the concern has been enhanced by numerous reports of hydrogen explosions in handling packages of uranium metal, varying from bottled uranium samples to shipping drums containing uranium metal corroded by moisture, wherein the uranium metal was stored in a sealed, moist inert gas or moist air environment. ${ }^{13,14,15}$ Many of these reports describe violent hydrogen explosions when the dry storage vessel was opened or penetrated, although only a few inferred the involvement of uranium hydride pyrophoricity.

Uranium hydride can form as a byproduct of uranium metal corrosion in certain conditions. The corrosion reaction has been postulated with various stoichiometric formulae: ${ }^{6,11}$

$$
\begin{aligned}
& 7 \mathrm{U}+6 \mathrm{H}_{2} \mathrm{O} \longrightarrow 4 \mathrm{UH}_{3}+3 \mathrm{UO}_{2} \\
& 2 \mathrm{U}+2 \mathrm{H}_{2} \mathrm{O} \longrightarrow \mathrm{UO}_{2}+\mathrm{UH}_{3}+1 / 2 \mathrm{H}_{2} \\
& \mathrm{U}+2 \mathrm{H}_{2} \mathrm{O} \longrightarrow \mathrm{UO}_{2}+2 \mathrm{H}_{2} \\
& 2 \mathrm{U}+3 \mathrm{H}_{2} \longrightarrow 2 \mathrm{UH}_{3}
\end{aligned}
$$

Because of its reactivity with both oxygen and water, the uranium hydride will react further to the oxide. The oxidation of uranium hydride has a significant thermodynamic driving force at $25^{\circ} \mathrm{C}$ :

$$
\begin{array}{ll}
\mathrm{UH}_{3}+7 / 4 \mathrm{O}_{2} \longrightarrow \mathrm{UO}_{2}+3 / 2 \mathrm{H}_{2} \mathrm{O} & \Delta \mathrm{F}_{298}=-315.5 \mathrm{kcal} / \mathrm{mole} \\
\mathrm{UH}_{3}+2 \mathrm{H}_{2} \mathrm{O} \longrightarrow \mathrm{UO}_{2}+7 / 2 \mathrm{H}_{2} & \Delta \mathrm{F}_{298}=-111.8 \mathrm{kcal} / \mathrm{mole}
\end{array}
$$

Oxygen can react rapidly and aggressively with the hydride, particularly if the hydride exists at high temperature or as a fine powder bed of high surface area, wherein enough heat can be generated to increase the oxygen diffusion rate in the partially protective oxide coating or to spall the coating from the hydride. Under such conditions the reaction can rapidly raise the temperature of the sample to incandescence. While the hydrogen that was produced by the corrosion reaction (or possibly by thermal dissociation of the hydride) can detonate upon ignition in air, the pyrophoric reaction itself has not been known to propagate to detonation.

The reaction with water is considerably less energetic and proceeds by non-linear kinetics. The rate of reaction, while initially fast, drops rapidly with exposure time. ${ }^{6}$ The hydride consumption rate 


\section{DISCLAIMER}

This report was prepared as an account of work sponsored by an agency of the United States Government. Neither the United States Government nor any agency thereof, nor any of their employees, makes any warranty, express or implied, or assumes any legal liability or responsibility for the accuracy, completeness, or usefulness of any information, apparatus, product, or process disclosed, or represents that its use would not infringe privately owned rights. Reference herein to any specific commercial product, process, or service by trade name, trademark, manufacturer, or otherwise does not necessarily constitute or imply its endorsement, recommendation, or favoring by the United States Government or any agency thereof. The views and opinions of authors expressed herein do not necessarily state or reflect those of the United States Government or any agency thereof. 


\section{DISCLAIMER}

This report was prepared as an account of work sponsored by an agency of the United States Government. Neither the United States Government nor any agency thereof, nor any of their employees, makes any warranty, express or implied, or assumes any legal liability or responsibility for the accuracy, completeness, or usefulness of any information, apparatus, product, or process disclosed, or represents that its use would not infringe privately owned rights. Reference herein to any specific commercial product, process, or service by trade name, trademark, manufacturer, or otherwise does not necessarily constitute or imply its endorsement, recommendation, or favoring by the United States Government or any agency thereof. The views and opinions of authors expressed herein do not necessarily state or reflect those of the United States Government or any agency thereof. 
becomes increasingly diffusion limited as the protective oxide layer forms on the hydride, and at ambient temperatures can result in the persistence of residual levels of hydride in the corrosion product.

The formation of hydride in spent uranium metal fuels is possible during corrosion of the fuel in underwater storage, during drying of the spent fuel in preparation for continued storage (either wet or dry), and during subsequent wet or 'dry' (humid) storage. The immediate concern is the potential pyrophoricity of heavily corroded spent fuel that is to be relocated from long-term underwater storage, which may result in the exposure of personnel and contamination of the facility. While the drying process and continued storage may also produce hydride, the hydride potentially formed during these processes can be prevented or minimized by appropriate passivation procedures and environmental control.

The potential pyrophoricity of BMI-SPEC and $\mathrm{UAl}_{\mathrm{x}}$ plate fuels is evaluated in this report in terms of the potential for metal auto-ignition and the potential for the hydride to ignite the bulk metal fuel. This evaluation summarizes the characteristics of the fuels of concern; the corrosion rate and mechanism of uranium corrosion; the effect of alloying and irradiation on corrosion rates; the hydride formation mechanism and hydride accumulation; and the ignition conditions in terms of some physical and compositional characteristics of uranium metal and uranium hydride.

\section{Spent Fuel Characteristics}

The spent fuels of immediate concern are some of the metal fuels presently stored in CPP-603 South Basin. As given in reference 1, these spent fuels are BMI-SPEC and the UAl $\mathrm{X}_{\mathrm{x}}$ plate fuels consisting of ATR, HFBR, MURR, and ORR.

\section{BMI-SPEC}

The BMI-SPEC spent fuel consists of one can of possibly three fuel plates that has been stored underwater at CPP-603 since 1959. The three fuel plates were part of two experimental OMR fuel assemblies, HB-1 and HT-1, irradiated in the Organic Moderated Reactor Experiment at the INEL in 1958. Some of the fuel plates in the assemblies were partially melted in the test irradiation, and were sent to Battelle Memorial Institute for examination. The plates are the remnants that were returned by BMI to the INEL for storage and reprocessing. ${ }^{16}$

The three fuel plates of uranium-3.5 wt\% molybdenum alloy were plated with nickel and clad with finned aluminum. The fuel structure consisted of a 0.130 inch thick plate of uranium-molybdenum fuel meat clad with 0.035 inch thick aluminum (minimum thickness of the finned cladding). The thickness of the nickel plating is not known. The general dimensions of the fuel plates are 12.1 inches long by 2.4 inches wide by 0.47 inches thick (thickness includes the height of the fins), while the fuel meat is 0.13 inch thick by 2.25 inches wide by 12 inches long. ${ }^{16}$ Descriptive documentation of the condition of the fuel specimens after examination is not available. 
On the basis of a past video inspection of the fuel after prolonged underwater storage, reference 16 indicated that the aluminum can was heavily corroded, but that the fuel cladding was "free of corrosion product and dark in color". The lack of corrosion has been speculated to be the result of a coating of "carbonaceous residue" formed during irradiation. This report implies that the BMISPEC was stored as bare plates in a rectangular aluminum can with no lid. ${ }^{16}$ However, existing videotapes of BMI-SPEC in underwater storage do not show any evidence of bare fuel plates. The rectangular can appears to have a sealed top, though the open top may merely have filled with silt. The rectangular can is stored in an open bucket. Consequently, the as-stored condition cannot be corroborated with the available videotapes.

\section{$\underline{\text { UAl }} \times$ Plate Fuels}

The aluminum plate fuels under consideration include ATR, HFBR, MURR, and ORR. These spent fuels were shipped to CPP-603 in 1984-86. ${ }^{1}$ The plate fuels have been stored bare, with the aluminum-clad plates fully exposed to the basin water. Video inspection of the ATR fuel elements in the South Basin of CPP-603 did not show any evidence of general corrosion or scale formation on the external surfaces. Some localized corrosion on the external surfaces of the assemblies was evident as large nodules of corrosion product, primarily on the exposed top edges of the fuel plates; the nodules are indicative of pitting corrosion. Furthermore, some corrosion nodules were often located in the vicinity of the deformation of the fuel plates caused by the fuel transfer tool used for ATR fuel element handling at CPP-603. The extent of corrosion of the surfaces of the plates inside the stacked plate assembly (i.e., the walls of the cooling channels) is not known. However, the cladding of many individual fuel plates is most likely breached by pitting corrosion. An estimated $0.5 \%$ of the ATR elements sent to the ICPP for storage had failed in service. ${ }^{17}$ In addition, materials testing studies have indicated a loss of $\approx 2$ mils thickness of the cladding due to erosion-corrosion of the aluminum cladding in reactor service. Furthermore, ATR fuels stored in the high-purity water of the ATR canal have experienced pitting corrosion. ${ }^{17}$ Pitting corrosion in the fuel cladding can propagate at a rate of $\approx 2$ mils per year in storage, so that complete penetration of the cladding by pitting corrosion may happen in less than 10 years. $^{18}$

As shown in Table 1, the aluminum plate fuels are physically similar and appear to differ only by composition of the fuel meat at manufacture. Available records are inconsistent on the composition of the fuel meat of HFBR and ORR fuel (see notes a and $c$ in Table 1). ${ }^{16,19}$ The inventories of the HFBR and the ORR fuel stored in CPP-603 may consist of elements that were manufactured with $\mathrm{UAl}_{\mathrm{x}}$ and with $\mathrm{U}_{3} \mathrm{O}_{8}$ fuel meat. The ambiguity of the records is moot however; while the raw materials for the HFBR and ORR fuel meat may have been $\mathrm{U}_{3} \mathrm{O}_{8}$, the conditions of manufacture and reactor service will have converted substantial amounts of the uranium oxide to $\mathrm{UAl}_{\mathrm{x}}$. At the temperatures of manufacture and reactor service, both $\mathrm{UO}_{2}$ and $\mathrm{U}_{3} \mathrm{O}_{8}$ can react with the matrix aluminum: ${ }^{11}$

$$
\begin{aligned}
& 16 \mathrm{Al}+3 \mathrm{UO}_{2} \longrightarrow 3 \mathrm{UAl}_{4}+2 \mathrm{Al}_{2} \mathrm{O}_{3} \\
& 26 \mathrm{Al}+3 / 2 \mathrm{U}_{3} \mathrm{O}_{8} \longrightarrow 9 / 2 \mathrm{UAl}_{4}+4 \mathrm{Al}_{2} \mathrm{O}_{3} .
\end{aligned}
$$

These reactions involve solid state diffusion of the reactants between the fuel particles and the aluminum matrix. The reactions rates are an exponential function of temperature and are fast at 
elevated temperatures. For example, $\mathrm{U}_{3} \mathrm{O}_{8}$ reacts completely in 90 minutes at $610^{\circ} \mathrm{C} ; \mathrm{UO}_{2}$ reacts completely in a few hours at $600^{\circ} \mathrm{C}$, but requires several days at $500^{\circ} \mathrm{C} .11$ These temperatures bracket the hot-rolling and annealing temperatures used in manufacture, so that appreciable conversion of the uranium oxide to the aluminide is expected from manufacture. Moreover, fuel materials development tests on aluminum plate fuels have shown that fuel irradiation will drive the above reactions rapidly to completion at $200^{\circ} \mathrm{C}$ at low burnup, or at $100^{\circ} \mathrm{C}$ at high burnup. ${ }^{2021}$ Since the HFBR and ORR plate fuels experienced high burnups ( $\approx 45 \%)$, these fuels are treated as $\mathrm{UAl}_{\mathrm{x}}$ fuels in this discussion.

Table 1. Summary of aluminum plate fuel characteristics. ${ }^{16}$

\begin{tabular}{|c|c|c|c|c|c|}
\hline $\begin{array}{l}\text { Fuel } \\
\text { Type }\end{array}$ & $\begin{array}{c}\text { Fuel } \\
\text { Composition } \\
\end{array}$ & $\begin{array}{l}\text { Fuel Meat } \\
\text { Thickness }\end{array}$ & $\begin{array}{l}\text { Cladding } \\
\text { Thickness }\end{array}$ & $\begin{array}{l}\text { Plates per } \\
\text { Assembly }\end{array}$ & $\begin{array}{l}\text { Assembly Geometry, } \\
\text { Dimensions }(\mathrm{tb} / \mathrm{w} / \mathrm{l})\end{array}$ \\
\hline ATR & $\begin{array}{l}\mathrm{UAl}_{\mathrm{x}} \text { powder } \\
\text { dispersed in } \mathrm{Al}\end{array}$ & $0.020^{\prime \prime}$ & $\begin{array}{l}0.008 \\
0.015^{\prime \prime}\end{array}$ & 19 & $\begin{array}{l}45^{\circ} \text { section of cylinder, } \\
2.55^{\prime \prime} \times 4.3^{\prime \prime} \times 49.5 \text { " }\end{array}$ \\
\hline HFBR & $\begin{array}{c}\mathrm{UAl}_{\mathrm{x}}, \mathrm{U}_{3} \mathrm{O}_{8} \\
\text { powder } \\
\text { dispersed in } \mathrm{Al} \\
\text { (a) }\end{array}$ & $0.0228 "$ & $0.0135 "$ & $\begin{array}{l}18 \\
\text { (b) }\end{array}$ & $\begin{array}{l}\text { curved plate array, } \\
2.88 \text { " } \times 3.22 \text { " } \times 24.5 "\end{array}$ \\
\hline MURR & $\begin{array}{l}\mathrm{UAl}_{\mathrm{x}} \text { powder } \\
\text { dispersed in } \mathrm{Al}\end{array}$ & $0.020 "$ & $0.015 "$ & 24 & $\begin{array}{c}45^{\circ} \text { section of cylinder, } \\
3.05^{\prime \prime} \times 3.6^{\prime \prime} \times 26.5^{\prime \prime}\end{array}$ \\
\hline ORR & $\begin{array}{c}\mathrm{UAl}_{\mathrm{x}}, \mathrm{U}_{3} \mathrm{O}_{8} \\
\text { powder } \\
\text { dispersed in } \mathrm{Al} \\
\text { (c) }\end{array}$ & $0.020^{\prime \prime}$ & $0.015^{\prime \prime}$ & 19 & $\begin{array}{c}\text { curved plate array, } \\
2.99 " \times 3.16 " \times 25.625 "\end{array}$ \\
\hline
\end{tabular}

a. Reference 16 gives the composition of HFBR fuel meat as $\mathrm{U}_{3} \mathrm{O}_{8}$ dispersed in aluminum, whereas the ICPP Fuel Receipt Criteria records indicate that the HFBR inventory consists of elements with $\mathrm{UAl}_{\mathrm{x}}$ and elements with $\mathrm{U}_{3} \mathrm{O}_{8}$ powder dispersed in aluminum powder matrix. $^{19}$

b. Type KM HFBR elements are stored in CPP-603. ${ }^{16}$ Type KM assemblies consist of 18 fuel plates and 2 non-fuel end plates.

c. Reference 16, which summarized several Oak Ridge Research Reactor documents, indicated that initially the ORR reactor was fueled with elements consisting of $\mathrm{UAl}_{\mathrm{x}}$ alloy powder dispersed in $\mathrm{Al}$ powder, whereas later fuel elements consisted of $\mathrm{U}_{3} \mathrm{O}_{8}$ powder dispersion in Al matrix. The ICPP Fuel Receipt Criteria records (memo ZIM-41-83) indicated that the ORR fuels in CPP-603 storage are the $\mathrm{UAl}_{\mathrm{x}}$ dispersion type. ${ }^{19}$

\section{Corrosion and Uranium Hydride Accumulation in Stored Spent Fuel}

The hydride that potentially accumulates in stored spent fuels is a function of the extent of corrosion 
of the metal fuel matrix, the rate of hydride formation, and the extent of hydride reaction (and passivation) with water or air. These factors are in turn dependent on specific exposure conditions, and are discussed in the following sections.

\section{Corrosion of Uranium Metal}

The corrosion rates for uranium metal by water has been defined primarily for solid-vapor phase corrosion in oxygenated and de-oxygenated conditions. The corrosion rate for liquid immersion is equivalent to the rate for saturated (condensing) vapor conditions and is given for oxygenated and de-oxygenated conditions in Table $2.22,23$ The rate of corrosion is approximately 40 times faster for de-oxygenated water than aerated water. The integrated rate of corrosion, expressed as weight gain per unit area $(\triangle M / A)$, is linear with time $(t)$

$$
\Delta \mathrm{M} / \mathrm{A}=\mathrm{kt}+\mathrm{c},
$$

where $\mathrm{k}$ is the corrosion rate coefficient at some defined temperature. In the case of solid-vapor phase corrosion (e.g., during the drying of the retrieved fuel and dry storage of incompletely dried fuel), the rate of corrosion is only weakly dependent on water vapor pressure in the range of 2 to 90 $\%$ relative humidity $(\mathrm{RH}){ }^{24,25}$

Table 2. Summary of reaction rate coefficients for uranium corrosion by dry oxygen and water. Data are average values derived by Ritchie in his review of the literature.

\begin{tabular}{|c|c|c|c|}
\hline $\begin{array}{l}\text { Reaction Conditions } \\
\text { (a) }\end{array}$ & $\begin{array}{c}\text { Corrosion Rate Coefficient, } \\
\mathbf{k}, \\
\mathbf{m g ~} \mathbf{U} / \mathbf{c m}^{2} \mathbf{h r} \\
\text { (b) }\end{array}$ & $\begin{array}{c}\text { Temperature } \\
\text { Range, } \mathrm{K}\end{array}$ & $\begin{array}{l}\text { Rate Coefficient } \\
\text { at } 40^{\circ} \mathrm{C} \\
\mathrm{mg} \mathrm{U} / \mathrm{cm}^{2} \mathrm{yr}\end{array}$ \\
\hline Dry oxygen or air & $6.9 \times 10^{8} \exp (-18.3 / \mathrm{RT})$ & $313 \leq \mathrm{T} \leq 573$ & 1.01 \\
\hline $\begin{array}{c}\mathrm{H}_{2} \mathrm{O} \text { vap, } 100 \% \mathrm{RH}, \\
\text { or immersion }\end{array}$ & $3.2 \times 10^{8} \exp (-13.8 / \mathrm{RT})$ & $293 \leq \mathrm{T} \leq 373$ & 647 \\
\hline $\begin{array}{c}\mathrm{H}_{2} \mathrm{O} \text { vapor }+\mathrm{O}_{2} \text { (air), } \\
2-90 \% \mathrm{RH}, \\
\mathrm{O}_{2}>0.1 \%\end{array}$ & $\begin{array}{l}4.8 \times 10^{13} \exp (-25.0 / \mathrm{RT}) \\
5.7 \times 10^{14} \exp (-26.4 / \mathrm{RT}) \\
\text { (c) }\end{array}$ & $313 \leq T \leq 403$ & $\begin{array}{l}1.47 \\
1.83\end{array}$ \\
\hline $\begin{array}{c}\mathrm{H}_{2} \mathrm{O} \text { vapor }+\mathrm{O}_{2} \\
100 \% \mathrm{RH} \text { or } \\
\text { immersion, } \mathrm{O}_{2}>0.1 \%\end{array}$ & $4.6 \times 10^{9} \exp (-17.8 / \mathrm{RT})$ & $298 \leq T \leq 373$ & 15.0 \\
\hline
\end{tabular}

a) $\mathrm{RH}=$ relative humidity. 
b) Data from Ritchie, 1981. Exponent is in form of $\left(E_{2} / R T\right)$, with the energy of activation, $E_{2}$, in terms of $\mathrm{kcal} / \mathrm{mol}, \mathrm{R}=1.987 \times 10^{-3} \mathrm{kcal} / \mathrm{mol} \mathrm{K}$, and temperature, $\mathrm{T}$, in degrees Kelvin. Variations in surface finish, impurities, and alloying contaminants can alter the rate constants by several factors. The rate coefficient has a strong dependence on temperature, but only a very weak dependence on water vapor in the range of $2-90 \%$ relative humidity at any given temperature, and none for oxygen pressures greater than $1 \mathrm{~mm} \mathrm{Hg}$.

c) Data from Ritchie 1986.

\section{Corrosion of Uranium Alloys}

Alloying elements can affect the corrosion resistance of uranium in varying ways, depending on composition, fabrication parameters, irradiation, and corrosion parameters. Corrosion resistance can vary widely with composition of the alloy. For molybdenum and aluminum alloys of uranium, the addition of alloying elements at percentage levels can cause profound effects on the corrosion resistance of the alloy in water. ${ }^{7,11}$ Compositions with high concentrations of the additive element, particularly for $\mathrm{UAI}_{\mathrm{x}}$, generally improve corrosion resistance of the alloy.

Molybdenum alloys. Some alloys containing molybdenum appear to exhibit improved corrosion resistance in short term tests, both in water vapor and in water immersion tests at temperatures less than $100^{\circ} \mathrm{C}$. The improved resistance ranges from several factors to several orders of magnitude, depending the composition, metallurgical state of the alloy, and the duration of the test. ${ }^{11,26}$

Unfortunately, alloys containing Mo exhibit improved corrosion resistance only for short durations, usually only hours to weeks in accelerated tests in boiling water or steam. Invariably, alloys containing Mo equal to or less than $6 \mathrm{wt} \%$ perform substantially worse than uranium metal in long term testing. In tests in water vapor at $75^{\circ} \mathrm{C}$ or in boiling water $\left(100^{\circ} \mathrm{C}\right)$, compositions with less than $6 \mathrm{wt} \%$ Mo exhibited severe attack. Within several weeks to several months, these alloys characteristically developed severe cracking that lead to an acceleration of the corrosion rate, and the complete disintegration of the alloy within a few months to a few years. The mechanism of attack and disintegration was the deep transgranular penetration of the alloy by the $\mathrm{UH}_{3}$ that was precipitated by the corrosion reaction. The amount of hydrogen necessary to cause precipitation and failure was as low as 10 to $25 \mathrm{ppm}$. This amount is equal to about $0.5 \%$ of the hydrogen released by the corrosion reaction and about $0.65 \% \mathrm{UH}_{3}$ (relative to the mass of corrosion product) at the reaction interface, ${ }^{7,11,26}$

The composition of the BMI-SPEC spent fuel, consisting of $3.5 \mathrm{wt} \% \mathrm{Mo}$, falls within the deleterious range of compositions. Since the fuel has been in underwater storage for 35 years, and at minimum has the cladding breached by previous destructive sampling, the likelihood of extensive corrosion and possibly disintegration is high. At the very least, the available data indicate that at $75^{\circ} \mathrm{C}$ the corrosion rates for the Mo alloys exceed the rate for uranium metal within a year, and as the alloy disintegrates, can rapidly accelerate to rates that are 10 to 100 times faster than uranium metal. ${ }^{7}$ While storage temperatures for BMI-SPEC are significantly lower, the length of storage in water argues for a degree of corrosion that is at least an order of magnitude worse than indicated for pure uranium metal. 
Aluminum alloys. Alloying tends to impart some degree of corrosion resistance to uranium, although the effect varies considerably with composition. Low levels of aluminum in uranium, up to 6 atomic $\% \mathrm{Al}\left(\mathrm{UAl}_{0.06}\right)$, improve the corrosion resistance of uranium; the effect is optimum at 0.2 atomic \% Al, which improves corrosion resistance by more than eight times. ${ }^{26}$ The corrosion resistance of alloys with more than 6 atomic \% Al depends greatly on composition. $\mathrm{U}_{2} \mathrm{Al}$ (33 atomic $\% \mathrm{Al}$ ) corrodes readily and slowly disintegrates in water. ${ }^{26}$ However, the intermetallic alloys present in the aluminum plate fuels, usually mixtures of $\mathrm{UAl}_{2}, \mathrm{UAl}_{3}$, and $\mathrm{UAl}_{4}$, are considerably more corrosion resistant than uranium metal, but less resistant than aluminum. ${ }^{11,26}$

Uranium metal and the $\mathrm{UAl}_{\mathrm{x}}$ alloys are generally considered anodic to aluminum, and corrode faster when coupled with aluminum. ${ }^{26,27,28} \mathrm{UAl}_{\mathrm{x}}(\mathrm{x} \approx 3)$ corroded approximately twice as fast as 8001 aluminum at $\approx 290^{\circ} \mathrm{C} .^{29,30}$

Large scale general corrosion of aluminum proceeds at a much slower rate than uranium metal in water of neutral $\mathrm{pH}$, as shown in Table $3 .^{31}$ Therefore, the preferential stripping of the aluminum cladding by general corrosion, and the exposure and general corrosion of the fuel meat is highly unlikely in the 10 year storage time.

However, the aluminum cladding of the aluminum fuel plates is highly susceptible to localized pitting corrosion. As indicated by the empirical relationship,

$$
\text { pit deepening rate }(\mathrm{mm} / \mathrm{s})=2.53 \times 10^{-5} \exp [-2898.5 / \mathrm{T}] \text {, }
$$

where $\mathrm{T}$ is the temperature in Kelvins, pitting corrosion proceeds at significantly faster rates than general corrosion of aluminum. ${ }^{32}$ At $40^{\circ} \mathrm{C}$, the pit deepening rate is 0.05 to $0.075 \mathrm{~cm} /$ year ( 2 to 3 mils per year), ${ }^{18,33}$ which means complete penetration of the cladding in 5 to 7 years of underwater storage. The microstructure of the fuel meat under the cladding consists of a discontinuous dispersion of $\mathrm{UAl}_{\mathrm{x}}$ powder (average size $\approx 45 \mu \mathrm{m}, 10-150 \mu \mathrm{m}$ range) in an aluminum alloy matrix wherein the individual $\mathrm{UAl}_{\mathrm{x}}$ particles are completely bounded and separated by the aluminum metal matrix. . $^{17,28,34,35,36,37,38}$ Therefore, localized penetrations due to pitting corrosion will result in the direct exposure of only a small number of $\mathrm{UAl}_{\mathrm{x}}$ particles to further corrosion.

Table 3. Comparison of corrosion rates for aluminum and uranium.

\begin{tabular}{|c|c|c|c|}
\hline & $\begin{array}{c}\text { Rate at } 40^{\circ} \mathrm{C}, \\
\mathrm{mg} \mathrm{metal} / \mathrm{cm}^{2} \mathrm{hr}\end{array}$ & $\begin{array}{c}\text { Rate at } 40^{\circ} \mathrm{C}, \\
\text { g-atom metal } / \mathrm{cm}^{2} \mathrm{hr}\end{array}$ & $\begin{array}{c}\text { Penetration Rate at } 40^{\circ} \mathrm{C}, \\
\mathrm{cm} / \mathrm{yr}\end{array}$ \\
\hline Aluminum & $9.9 \times 10^{-6}$ & $3.7 \times 10^{-10}$ & $3.2 \times 10^{-5}$ \\
\hline Uranium & $1.7 \times 10^{-3}$ & $7.2 \times 10^{-9}$ & $7.9 \times 10^{-4}$ \\
\hline
\end{tabular}




\section{Effect of Irradiation on Corrosion}

The corrosion reaction, and the rate of corrosion, is not affected by a radiation field. For example, the corrosion rate was not affected by $\approx 72 \mathrm{Mrad}$ of ${ }^{60} \mathrm{Co}$ gamma radiation at $30^{\circ} \mathrm{C} .{ }^{6}$ However, the rate of corrosion is sensitive to the damage induced by neutron irradiation in the fuel, and is primarily the consequence of the porosity and the increased surface area due to irradiation swelling.

The effect of irradiation-induced swelling on the rate of corrosion can be substantial; however swelling becomes appreciable only in fuels with moderate to high burnup. A conservative correction for the effect of irradiation-induced swelling on the corrosion of uranium metal can be expressed as

$$
\begin{aligned}
k_{\text {ir }} & =(1+\Delta V / V)^{n} k_{u n} \\
& =(1+\Delta V / V)^{n} k_{0} \exp \left[-E_{\mathrm{a}} / R T\right]
\end{aligned}
$$

where $k_{\text {ir }}$ is the adjusted corrosion rate for irradiated material, $\Delta V / V$ is the fractional extent of radiation swelling, $n$ is an index relating swelling to surface area, $k_{u n}$ is the corrosion rate for unirradiated material (see Table 2), and $\mathrm{k}_{0}$ is the temperature independent rate constant whose value is the pre-exponential term in the expressions given in Table $2 . .^{39}$ For tests at $75-140^{\circ} \mathrm{C}$ in Magnox fuel storage conditions $\left(\mathrm{NaOH}\right.$ solutions containing $1 \mathrm{~kg} / \mathrm{m}^{3}$ fluoride, and $\Delta \mathrm{V} / \mathrm{V}$ ranging from 0.05 to 0.50 ), Tyfield determined a value of 9 for $n^{39}$ An alternative correction that includes the effects of the irradiation temperature at which swelling occurs is

$$
\mathrm{k}_{\mathrm{irr}}=\mathrm{k}_{\mathrm{un}} \exp \left[1.94 \times 10^{6}(\Delta \mathrm{V} / \mathrm{V}) / \mathrm{T}^{2}\right]
$$

where the fuel meat temperature during irradiation, $\mathrm{T}$, is expressed in Kelvins. ${ }^{25}$

BMI-SPEC was an experimental fuel that was irradiated in the Organic Moderated Reactor Experiment performance tests at the INEL. ${ }^{16}$ The burn up of the fuel in BMI-SPEC was low, on the order of 4 to $11 \%$. ${ }^{1,16}$ The irradiation swelling of theses samples is negligible and will not increase the rate of corrosion.

The aluminum plate spent fuels have seen significant burn ups. ${ }^{1}$ The MURR spent fuels have a burn up of $24 \%$, the ATR spent fuel $=40 \%$, and the HFBR and ORR spent fuels $\approx 45 \%$. For UAl $\mathrm{I}_{\mathrm{x}}$ plate fuels, the extent of swelling $\Delta \mathrm{V} / \mathrm{V}$ can be determined from the fission density $\mathrm{F}$ (average burn up in units of fissions $/ \mathrm{cm}^{3}$ of core) by the empirical expression ${ }^{18,36,37}$

$$
\triangle \mathrm{V} / \mathrm{V}=0.026 \mathrm{~F} /\left(10^{21} \text { fissions } / \mathrm{cm}^{3} \text { of core }\right)
$$

The relative burn up in $\mathrm{UAl}_{\mathrm{x}}$ plate fuels varies with fuel loading, but is proportional to fission density for a constant fuel loading. ${ }^{18,36,37}$. For ATR-type fuel plates with high core loading (55-63 $\mathrm{wt} \% \mathrm{UAl}_{3}$, or $3.6-4.4 \times 10^{21}$ atoms $\mathrm{U} / \mathrm{cm}^{3}$ of core), fractional swelling $\Delta \mathrm{V} / \mathrm{V}$ from irradiation damage is related to $\%$ burnup (B) by ${ }^{36.38}$

$$
\Delta \mathrm{V} / \mathrm{V}=0.0011 \mathrm{~B} .
$$


While Beeston et al. indicated that relationship 6 is valid for irradiation at temperatures up to $200^{\circ} \mathrm{C}$, Dienst et al. indicated that the relationship is valid for fuel meat temperatures only up to $70^{\circ} \mathrm{C}$. At temperatures of $150-180^{\circ} \mathrm{C}$, twice as much swelling occurred for irradiations beyond $35-40 \%$ burnup. ${ }^{38}$ ATR fuels were irradiated to a burn-up of $\approx 40 \%$ at a mean fuel meat temperature of $120^{\circ} \mathrm{C},{ }^{40}$ and may have fractional swelling of $0.044-0.050$ and possibly as much as 0.10 . Thus, according to equations 3 and 4 , the corrosion rate of uranium metal powder in the irradiated aluminum plate fuels may be enhanced by approximately $50 \%$ to $75 \%$. Because the above swelling correction factors for the corrosion rates were derived from and for the corrosion behavior of uranium metal fuels, the corrections may not be accurate for the corrosion rates of $\mathrm{UAl}_{\mathrm{x}}$ alloys. Since the uranium density is much lower in $\mathrm{UAl}_{\mathrm{x}}$ fuels, the effect of swelling on the corrosion rate constant may be lower than as given by equations 3 and 4 . Nevertheless, the calculated corrections do suggest that the swelling of the aluminum plate fuels increases the corrosion rate of the UAlx alloy moderately.

Because swelling is a function of fission product content, these corrections probably do not apply to the aluminum cladding or matrix. Microanalyses of $\mathrm{UAl}_{\mathrm{x}}$ fuel plates by Dienst et al. indicated that the irradiation affected the fuel powder and to a limited extent the aluminum matrix, but did not affect the cladding. ${ }^{38}$ This suggests that a similar swelling correction to general corrosion or pitting corrosion rates is not appropriate for the aluminum cladding or the matrix of the aluminum plate fuels.

Therefore, the above correction factors suggest that irradiation swelling further enhances the reactivity of the $\mathrm{UAl}_{\mathrm{x}}$ fuel meat with respect to the cladding and the aluminum matrix. Once the aluminum cladding is penetrated by pitting corrosion, the exposed swollen uranium powder alloy may react even more rapidly with respect to the cladding and the matrix, and may ensure the complete reaction of the dispersed $\mathrm{UAl}_{\mathrm{x}}$ powder (and the residual $\mathrm{UH}_{3}$ ) before further powder particles are exposed by corrosion of the aluminum matrix.

\section{Corrosion and Hydride Formation Mechanisms}

Uranium hydride is a partial product of the corrosion reaction at the oxide-metal interface. Several literature reports have documented the formation of uranium hydride in the initial stages of the corrosion reaction in closed, gas-solid phase reaction systems. ${ }^{6,7,9,12}$ However, more recent work in open flow reaction systems have failed to detect the formation of hydride in the initial reactions at the metal surface using sophisticated surface spectroscopy methods. ${ }^{24,41,42,43}$ Nevertheless, in the corrosion of uranium metal, the mass of uranium consumed is usually greater than the amount of free hydrogen released by the reaction, as predicted by the stoichiometry of the reaction

$$
\mathrm{U}+2 \mathrm{H}_{2} \mathrm{O} \longrightarrow \mathrm{UO}_{2}+2 \mathrm{H}_{2} \text {. }
$$

The deficit in the evolved hydrogen has been attributed to the production of uranium hydride in addition to the hyperstoichiometric $\mathrm{UO}_{2}$. Also, thin $(<2 \mu \mathrm{m})$ discontinuous films of $\mathrm{UH}_{3}$, have been identified at the corrosion interface of metal fuels stored in basins. ${ }^{39}$ 
From a consideration of the reaction mechanisms involved in the corrosion of uranium metal by oxygen-free water, whether in vapor-solid or liquid-solid phase reactions, the net reaction at the interface can be summarized as:

$$
5 \mathrm{U}+6 \mathrm{H}_{2} \mathrm{O} \longrightarrow 3 \mathrm{UO}_{2+\mathrm{x}}+2 \mathrm{UH}_{3}+3 \mathrm{H}_{2} .
$$

The corrosion reaction mechanism consists of the formation and diffusion of $\mathrm{OH}^{-}$or $\mathrm{O}^{2-}$ ions through the oxide layer to the reaction interface. ${ }^{6,7,24,41-43}$ For the water reaction in an oxygen-free system, the mechanism involves the steps:

- adsorption of molecular water on the surface of the oxide layer;

- dissociation of the water molecule at the surface of the oxide layer

$$
\begin{aligned}
& \mathrm{H}_{2} \mathrm{O} \longrightarrow \mathrm{OH}^{-}+\mathrm{H}^{+} \\
& 2 \mathrm{H}^{+}+2 \mathrm{e}^{-} \longrightarrow \mathrm{H}_{2}
\end{aligned}
$$

- diffusion of the $\mathrm{OH}$ - through the oxide layer; and

- reaction of the $\mathrm{OH}$ - at the oxide-metal interface

$$
\begin{aligned}
& \mathrm{U} \longrightarrow \mathrm{U}^{4+}+4 \mathrm{e}^{-} \\
& \mathrm{OH}-\longrightarrow \mathrm{O}^{2-}+\mathrm{H}^{+} \\
& \mathrm{U}^{4+}+2 \mathrm{O}^{2-} \longrightarrow \mathrm{UO}_{2} \\
& \mathrm{H}^{+}+\mathrm{e}^{-} \longrightarrow \mathrm{H} \cdot \\
& \mathrm{U}+3 \mathrm{H} \cdot \longrightarrow \mathrm{UH}_{3} .
\end{aligned}
$$

The agency of the $\mathrm{OH}^{-}$anion and the formation of $\mathrm{UO}_{2}$ at the interface have been corroborated by recent investigations of the reaction mechanism by surface-sensitive spectroscopy, including X-ray photoelectron spectroscopy, Auger electron spectroscopy, secondary ion mass spectroscopy, thermal desorption spectroscopy, and electron-induced luminescence. However, these investigations have not been able to produce direct spectroscopic evidence for the formation of $\mathrm{UH}_{3}$ at the reaction interface. ${ }^{24,41-43}$

In vapor-solid phase reaction, oxygen at levels as low as 100 ppm inhibit the $\mathrm{U}-\mathrm{H}_{2} \mathrm{O}$ corrosion reaction. Oxygen levels greater than $1000 \mathrm{ppm}$ fully inhibit the vapor phase corrosion reaction, resulting in a suppression of the corrosion rate and the cessation of free hydrogen evolution and hydride formation. Available data suggest that oxygen-modified corrosion proceeds by the following mechanism: $:^{24,41-43}$

- adsorption of $\mathrm{O}_{2}$ on the surface of the oxide layer, preferentially displacing water;

- dissociation of the adsorbed $\mathrm{O}_{2}$ to the $\mathrm{O}^{2-}$ ion at the oxide surface;

$$
\mathrm{O}_{2}+4 \mathrm{e}^{-} \longrightarrow 2 \mathrm{O}^{2-}
$$

- slow diffusion of the anion through the oxide layer; and

- reaction with the metal at the oxide-metal interface.

$$
\mathrm{U}^{4+}+2 \mathrm{O}^{2-} \longrightarrow \mathrm{UO}_{2}
$$

The reaction forms only hyperstoichiometric $\mathrm{UO}_{2}$ with no free hydrogen or uranium hydride. As long as oxygen is present at greater than $1000 \mathrm{ppm}$, adsorption of water and diffusion of $\mathrm{OH}^{-}$is prevented. ${ }^{24,41-43}$ Once the oxygen is consumed, the reaction reverts to uninhibited corrosion as described by reaction equations $9-15 .^{44}$ 
While oxygen suppresses the rate of liquid-solid phase corrosion, aeration of water neither fully inhibits the $\mathrm{U}-\mathrm{H}_{2} \mathrm{O}$ corrosion reaction, nor prevents the formation of free hydrogen or $\mathrm{UH}_{3}$. Oxygensaturated water contains only $5 \mathrm{ppm} \mathrm{O}_{2}\left(\right.$ at $\left.25^{\circ} \mathrm{C}\right), 45,46$ far below the threshold for prevention of hydride formation. Therefore the reduced efficacy of oxygen in liquid water corrosion is probably caused by insufficient dissolved oxygen to saturate the adsorption sites on the oxide surface and to block water adsorption completely. The products from various corrosion conditions are summarized in Table 4.

Table 4. Correlation of conditions and products from the corrosion of uranium metal.

\begin{tabular}{|c|c|}
\hline Reaction Conditions (Type) & Products \\
\hline Dry oxygen or air & $\mathrm{UO}_{2+\mathrm{x}}, \mathrm{x} \approx 0.06-0.09$ \\
\hline $\mathrm{H}_{2} \mathrm{O}$ vapor, 2-90\% RH & $\mathrm{UO}_{2+\mathrm{x}}(0.06<\mathrm{x}<0.25)$, free $\mathrm{H}_{2}$, some $\mathrm{UH}_{3}$ \\
\hline $\begin{array}{c}\mathrm{H}_{2} \mathrm{O} \text { vapor, } 100 \% \mathrm{RH} \text {, or } \\
\text { immersion }\end{array}$ & $\mathrm{UO}_{2+\mathrm{x}}(0.06<\mathrm{x}<0.25), \mathrm{UO}_{3} \mathrm{x} 0.8 \mathrm{H}_{2} \mathrm{O}$, free $\mathrm{H}_{2}$, some $\mathrm{UH}_{3}$ \\
\hline $\begin{array}{c}\mathrm{H}_{2} \mathrm{O} \text { vapor }+\mathrm{O}_{2} \text { (air), } \\
2-90 \% \mathrm{RH} \mathrm{H} \mathrm{H}_{2} \mathrm{O} \mathrm{O}_{2}>0.1 \%\end{array}$ & $\mathrm{UO}_{2+\mathrm{x}}(0.06<\mathrm{x}<0.25) ;$ no $\mathrm{H}_{2}$, no $\mathrm{UH}_{3}$ \\
\hline $\begin{array}{c}\mathrm{H}_{2} \mathrm{O} \text { vapor }+\mathrm{O}_{2} \text { (air), } \\
100 \% \mathrm{RH} \mathrm{H} \mathrm{H}_{2} \mathrm{O} \text { or immersion, } \\
\mathrm{O}_{2}>0.1 \%\end{array}$ & $\mathrm{UO}_{2+\mathrm{x}}(0.06<\mathrm{x}<0.25), \mathrm{UO}_{3} \mathrm{x} 0.8 \mathrm{H}_{2} \mathrm{O}$, free $\mathrm{H}_{2}$, some $\mathrm{UH}_{3}$ \\
\hline
\end{tabular}

\section{Hydride Concentration in the Corrosion Product}

The rate of hydride accumulation in corroding metal depends on the rate of metal corrosion, the rate of hydride formation, and the rate of hydride passivation by water or oxygen. The reaction stoichiometry of equation 8 , which is a summary of the reaction mechanism described by reaction sequence 9-15, implies that the instantaneous rate of hydride formation is equivalent to $40 \%$ of the reaction rate of uranium metal. Assuming no further reaction of the hydride, the corrosion reaction (equation 8) would stoichiometrically produce $40 \mathrm{~mole} \% \mathrm{UH}_{3}$ in the products at the corrosion interface, and the hydride formation rate would be equivalent to $40 \%$ of the rates given in Table 2 .

However, the hydride reacts further with water. Ideally, reaction 8 implies that $50 \%$ of the hydrogen entering the reaction as water could potentially form uranium hydride while the remaining $50 \%$, or 0.6 moles $\mathrm{H}_{2}$ per gram-atom uranium metal, would be released as free hydrogen. In fact, the literature on closed-system corrosion of uranium metal indicate that more than 1.6 moles free hydrogen evolves from reaction of one gram-atom uranium metal. This represents a $160 \%$ excess yield of hydrogen over the stoichiometry of reaction 8 , yet less than $80 \%$ of stoichiometric yield as calculated from the simpler corrosion reaction 7. $6,9,11$ Therefore, either the hydride is not produced 
stoichiometrically at the reaction interface as indicated by reaction 8 , or, more likely, a significant amount of the hydride formed at the reaction interface reacts immediately further with water.

Quantitative data on hydride accumulation as a function of corrosion time in liquid water or vapor is almost non-existent. However, a first order approximation of residual hydride content in corroding uranium can be derived from data given in references 6 and 9. An empirical relationship, a reciprocal power function regression fit, was determined for the relative amount of hydride in the total corrosion product mass as a function of corrosion time. The corrosion data ${ }^{9}$ at $60^{\circ} \mathrm{C}$ fit the empirical form

$$
\left[\mathrm{UH}_{3}\right]_{60^{\circ} \mathrm{C}}=0.414 \mathrm{t}^{-0.67}
$$

where $\left[\mathrm{UH}_{3}\right]$ is the mass fraction of $\mathrm{UH}_{3}$ in the accumulated corrosion product and $t$ is the corrosion time in hours at $60^{\circ} \mathrm{C}$ and $55 \%$ relative humidity. Data for hydride accumulation in corrosion at $\approx 115^{\circ} \mathrm{C}$ and $\approx 150^{\circ} \mathrm{C}$, though incomplete and characterized by considerable scatter, ${ }^{6}$ yielded similar empirical fits,with surprisingly similar coefficients and exponents.

Baker et al. published limited data, with minimal interpretation, on the reaction of pure $\mathrm{UH}_{3}$ powder (produced by gas phase hydriding of metal, not by corrosion of uranium metal) in water vapor at $100^{\circ} \mathrm{C}$ and $100 \%$ relative humidity (equivalent to full immersion). ${ }^{6}$ When appropriately transformed, their data fit an empirical $t^{-1 / 2}$ relationship

$$
\left[\mathrm{UH}_{3}\right]_{100^{\circ} \mathrm{C}}=1.46 \mathrm{t}^{-0.498} \text {. }
$$

The form of the empirical fit suggests that the reaction of uranium hydride is governed by diffusion of water through the forming oxide layer.

An empirical relationship for estimating the residual uranium hydride in corrosion product has been approximated numerically. The function is based on the corrosion rate at $40^{\circ} \mathrm{C}$ for aerated water, as derived from the expression given in Table 2 , and a formation stoichiometry as given by equation 8. The approximation includes an expression for the simultaneous depletion of $\mathrm{UH}_{3}$ at $40^{\circ} \mathrm{C}$ that has been estimated from corrosion data in Kondo et al. ${ }^{9}$ and Baker et al. ${ }^{6}$ Thus, the mass fraction of residual uranium hydride remaining in the corrosion product mass, for corrosion at $40^{\circ} \mathrm{C}$, can be estimated from the relationship

$$
\left[\mathrm{UH}_{3}\right]_{40 \cdot \bullet}=2.5 t^{-0.58}
$$

as a function of corrosion time $(t)$ in hours.

Until better data become available, Equations 17 and 19 may serve to bound order of magnitude projections of the relative quantity of residual hydride in corroded fuel. Equation 17, obtained from residual $\mathrm{UH}_{3}$ in metal samples corroded at $60^{\circ} \mathrm{C}$, and equation 19 , empirically derived from corrosion rates and $\mathrm{UH}_{3}$ depletion at $40^{\circ} \mathrm{C}$, both indicate that while the relative $\mathrm{UH}_{3}$ content in the corrosion product decreases rapidly initially, some residual hydride may persist even at long exposure times, albeit at low levels. This is shown by the sample calculations in Table 5 using both 
equations. The differences in the calculated residual $\mathrm{UH}_{3}$ levels in Table 5 reflect in part the difference in reaction temperatures central to each equation, conservatism in the depletion factors in equation 19, and uncertainties in the depletion kinetics.

A significant uncertainty in the use of equations 17 and 19 is that they are based on laboratory experiments of short duration relative to the time scale of fuel storage. Extrapolations of these equations to long exposure time will have considerable uncertainty. Such extrapolations are valid only as order of magnitude projections, particularly since many material and configuration characteristics affect the rate of corrosion, as well as hydride formation and depletion. Furthermore, the laboratory data on which these projections are based are sparse. Specifically, data pertaining to residual $\mathrm{UH}_{3}$ in corrosion product, or the hydrolysis of pure $\mathrm{UH}_{3}$, are almost non-existent, and the rate constants and the activation energy of the reaction are not known. The problem may be compounded by the possibility that the physical microstructure of the uranium oxide layer on the $\mathrm{UH}_{3}$ may be strongly affected by the temperature at which the corrosion product is formed, and may influence the activation energy and rate constants of the reaction. However, the above empirical functions are suitable for order of magnitude estimates of hydride content.

Table 5. The relative amount of residual uranium hydride in the corrosion layer, as well as the corrosion layer thickness, is given as a function of corrosion time. (The extent of corrosion has not been adjusted for specific fuel characteristics. The relative amount of $\mathrm{UH}_{3}$ in the corrosion product decreases with time of exposure to water.)

\begin{tabular}{|c|c|c|c|c||}
\hline $\begin{array}{c}\text { Corrosion } \\
\text { Time, } \\
\text { yrs. }\end{array}$ & $\begin{array}{c}\text { De-aerated } \mathrm{H}_{2} \mathrm{O}: \\
\text { Corrosion Layer } \\
\text { Thickness, mm }\end{array}$ & $\begin{array}{c}\text { Oxygenated } \mathrm{H}_{2} \mathrm{O}: \\
\text { Corrosion Layer } \\
\text { Thickness, mm }\end{array}$ & $\begin{array}{c}\text { Residual } \mathrm{UH}_{3}, \\
\% \\
(1)\end{array}$ & $\begin{array}{c}\text { Residual } \mathrm{UH}_{3}, \\
\% \\
(2)\end{array}$ \\
\hline 1 & 0.59 & 0.014 & 0.1 & 1.26 \\
\hline 5 & 2.9 & 0.068 & 0.032 & 0.50 \\
\hline 10 & 5.9 & 0.14 & 0.020 & 0.33 \\
\hline 15 & 8.8 & 0.20 & 0.016 & 0.26 \\
\hline 20 & 11.8 & 0.27 & 0.013 & 0.22 \\
\hline 30 & 17.6 & 0.41 & 0.010 & 0.17 \\
\hline
\end{tabular}

1) Projections based on the corrosion data of Kondo et al. ${ }^{9}$ Calculated from equation 17, an empirical fit to residual $\mathrm{UH}_{3}$ data derived from corrosion data obtained at $60^{\circ} \mathrm{C}$ by Kondo et al. ${ }^{9}$

2) Calculated from equation 19 , empirically derived for reaction at $40^{\circ} \mathrm{C}$ from corrosion rate constants from Ritchie ${ }^{22}$ and from $\mathrm{UH}_{3}$ depletion data from Kondo and Baker et al. ${ }^{6}$ 


\section{Ignition Conditions}

The potential pyrophoricity of corroded spent metal fuels has generally focussed on the ignition of the uranium metal by the combustion of the residual $\mathrm{UH}_{3}$ in the corrosion layer. However, the pyrophoricity of corroded uranium metal actually involves two separate issues: the ignition of the metal by the pyrophoricity of the corrosion product $\left(\mathrm{UH}_{3}\right)$ and the intrinsic pyrophoricity of the bulk metal itself. For corroded spent nuclear fuels, the issues are whether the spontaneous combustion of the residual $\mathrm{UH}_{3}$ can ignite the metal substrate, or whether the ignition temperature of the metal has been reduced sufficiently by the radiation and corrosion history to render the metal inherently pyrophoric in ambient handling or processing conditions.

The phenomenon of pyrophoricity, the spontaneous combustion and ignition of a material, is the product of the thermodynamic and kinetic characteristics of the pyrophoric material and the heat transfer and heat dissipation characteristics of the material's physical configuration. Consequently, several intrinsic and extrinsic material characteristics, particularly the particle size of the material, and the heat loss characteristics are important factors in pyrophoricity. Applicable material characteristics and the results of an ignition model are briefly discussed in this section.

\section{Uranium Metal Pyrophoricity}

Any factors that decrease the ignition temperature of the metal will increase the pyrophoricity of the metal or the probability of ignition of the metal by the hydride. In general, factors that accelerate oxidation of the metal will also lower ignition temperatures and increase the probability of spontaneous ignition. Such factors are physical or chemical conditions that facilitate the contact of reactants (e.g., high surface area, high diffusion rate of $\mathrm{O}_{2}$, no protective oxides, pure and unlimited reactants) and maximize local heating (i.e., retarded heat dissipation, additional heat input). Specific factors that affect the ignition temperature of the uranium include the specific surface area (e.g., particle size, swelling, surface roughness, protective oxides), composition of the oxidizing gas, metal purity (including alloying additives and fission product content), metallurgical condition, and the heat dissipation characteristics of the metal.

Ignition Temperature of Uranium Metal. The characteristic ignition temperature of a material is that temperature at which the oxidation reaction (combustion) becomes rapid enough to 'flash' with the spectacular emission of light and intense heat. At this point, the combustion rate rises rapidly and exponentially, and sustains very high sample temperatures that are often in excess of $2000^{\circ} \mathrm{C}$ until the sample is largely consumed by the reaction. ${ }^{47}$

The characteristic ignition temperature of bulk uranium metal is in the range of 550 to $595^{\circ} \mathrm{C}$ in pure oxygen. ${ }^{47,48}$ However, the ignition temperature is usually preceded by self-heating of the sample, due to the pre-ignition oxidation (combustion) at lower temperatures. Such self-heating becomes evident at sample temperatures starting at 200 to $400^{\circ} \mathrm{C}$, depending on specific sample characteristics. ${ }^{47,49}$ 
Effect of Surface Area/Porosity. The ignition temperature of uranium metal is affected by several physical and chemical characteristics. The dominant characteristic is the specific surface area of the material, which is a function of the surface roughness ( e.g., surface roughening by corrosion), grain structure of the metal, porosity (e.g., radiation swelling), or the particle size distribution of the sample. The relationship between specific surface area $\left(A_{s}\right.$, in $\left.\mathrm{cm}^{2} / \mathrm{g}\right)$ and ignition temperature in oxygen ( $T$, in Kelvins) is ${ }^{47}$

$$
T=4190\left[\log A_{s}+5.23\right]^{-1} \text {. }
$$

Configuration can have a substantial effect on ignition temperature. Because of the increased specific surface area, the ignition temperature of 10 mil thick foil of uranium $\left(5 \mathrm{~cm}^{2} / \mathrm{g}\right)$ is $\approx 380^{\circ} \mathrm{C}$ compared to $=580^{\circ} \mathrm{C}$ for bulk metal. Furthermore, the ignition temperature can be reduced to $120^{\circ} \mathrm{C}$ by reducing the sample to a powder with a specific surface of $30 \mathrm{~m}^{2} / \mathrm{g}$, comparable to the specific surface area of corrosion product. ${ }^{6}$. The increased surface area due to the irradiation-induced $10 \%$ swelling of Magnox fuels decreased the spontaneous ignition temperature of the metal fuel to $\approx 275^{\circ} \mathrm{C}$. Consequently, the temperature limits for handling and storage of Magnox fuels have been set at less than or equal to $150^{\circ} \mathrm{C}$, with transients never to exceed $200^{\circ} \mathrm{C} .{ }^{50}$

These factors are expected to have minimal effects on the ignition temperature of the metal alloys of the BMI-SPEC and the aluminum plate fuels. For BMI-SPEC fuel plates, the 0.130 inch (130 mil) thickness of the metal and the aluminum cladding mass results in a minimal reduction of the ignition temperature, if any. Because BMI-SPEC had low burnup and insignificant swelling, the plates will not be porous or have any internal surface area; any surface area increase would be due only to surface roughening by corrosion. For the aluminum plate fuels, the aluminum cladding and matrix will protect the swollen but encapsulated $\mathrm{UAl}_{\mathrm{x}}$ grains from uncontrolled oxidation.

Effect of $\mathrm{O}_{2}$. Air, and Inert Gas Mixtures. The concentration of an oxidizer such as $\mathrm{O}_{2}$ also has a strong influence on the ignition temperature. In pure oxygen, the ignition temperature of uranium is $550-595^{\circ} \mathrm{C}$. As pure oxygen is diluted with an inert gas (e.g. helium) or nitrogen, the ignition temperature is increased (i.e., the sample becomes harder to ignite). For example, for mixtures containing helium, the ignition temperature gradually increased to $=630^{\circ} \mathrm{C}$ as the oxygen concentration was decreased from $100 \%$ to $40 \% \mathrm{O}_{2}$. As the mixture was diluted further below $40 \% \mathrm{O}_{2}$, the ignition temperature increased approximately $15^{\circ} \mathrm{C}$ for every $1 \%$ reduction in $\mathrm{O}_{2}$ concentration. At $13 \% \mathrm{O}_{2}$ in an inert gas, the reaction kinetics were reduced such that the ignition temperature was well above $1000^{\circ} \mathrm{C}$ and no longer differentiated from thermocyclical (self-limiting) combustion. Correspondingly, the maximum burning temperatures decreased from $2200^{\circ} \mathrm{C}$ for pure oxygen to $\approx 1000^{\circ} \mathrm{C}$ at $13 \% \mathrm{O}_{2}$. Furthermore, the maximum combustion temperature curves suggest that as the oxygen concentration in an inert gas is reduced below $13 \%$, the maximum combustion temperature drops rapidly to the point at which combustion cannot be sustained. ${ }^{47}$

Ignition of uranium is much more difficult in air than in pure oxygen, occurring above $660^{\circ} \mathrm{C}$. Ignition in air (just as in a 80-20 helium-oxygen mixture) does not produce the characteristic intense emission ('flash') of light and the exponential rise in combustion rate and temperature, nor is combustion sustained as in more concentrated oxygen mixtures. Instead, ignition in air results in 
self-heating combustion typified by cycling of the sample temperature between $800^{\circ} \mathrm{C}$ and $1500^{\circ} \mathrm{C} \cdot 47,48$

Air is much less effective in inhibiting ignition than a comparable mixture involving an inert gas. The ignition temperature of uranium was $\approx 660^{\circ} \mathrm{C}$ in air, and $\approx 1000^{\circ} \mathrm{C}$ in an $80-20$ helium-oxygen mixture. Air mixtures with a reduced oxygen content (below 20\%) were not as effective in raising the ignition temperature nor in reducing the maximum combustion temperature as a comparable inert gas mixture. These data suggest that the nitrogen in air will react with uranium at elevated temperatures and contribute to combustion heating. While there is some question whether true ignition can occur in air, air can still cause intense self-heating combustion, where the sample temperature can cycle between 800 and $1500^{\circ} \mathrm{C}$. Comparable inert gas mixtures are considerably more effective in moderating the combustion. ${ }^{47}$

Effect of Alloys. Impurities. Alloying additives and impurities, including fission products, can accelerate or hinder the formation of protective oxide films on the uranium during the pre-ignition oxidation, and thus can raise or lower the characteristic ignition temperature. The effects are usually greatest for low levels of additives, typically less than 1 atom $\%$ of the additive. Of particular interest in this evaluation were the effects of aluminum and molybdenum.

Aluminum additives decrease the ignition temperature substantially. The effect is greatest for 1 atom $\% \mathrm{Al}$, which depresses the ignition temperature from $\approx 575^{\circ} \mathrm{C}$ to $355^{\circ} \mathrm{C}$. The ignition temperature slowly increases for higher concentrations of aluminum. ${ }^{47,48}$ The data indicate that the $\mathrm{UAl}_{\mathrm{x}}$ compositions typical for the aluminum plate fuels are not characterized by low ignition temperatures or prone to accelerated combustion. In fact, because of the preponderance of $\mathrm{Al}$ in the alloy, the ignition and combustion characteristics are largely governed by the aluminum component which forms a highly-protective surface oxide upon oxidation.

Molybdenum additives initially decrease the ignition temperature, to $405^{\circ} \mathrm{C}$ for $0.2 \mathrm{wt} \% \mathrm{Mo}$, and substantially increase the ignition temperature at higher concentrations. For $0.8 \mathrm{wt} \% \mathrm{Mo}$, the ignition temperature is $605^{\circ} \mathrm{C}$, which suggests that the $3.5 \mathrm{wt} \% \mathrm{Mo}$ in the BMI-SPEC fuel will substantially passivate the fuel to combustion. ${ }^{47,48}$

\section{Uranium Hydride Pyrophoricity}

The issue of hydride pyrophoricity is whether there is sufficient hydride in the corrosion layer or in localized pockets to cause ignition of the hydride or significant self-heating by oxidation of the hydride, either of which could cause the ignition of the bulk uranium metal. The hydride ignition is of much greater concern, since the very intense localized heat produced by ignition of a relatively small mass of hydride could ignite the metal underneath. The feasibility of such a 'match-head' mechanism has been demonstrated by Schnizlein et al. ${ }^{47}$ The factors involved in the $\mathrm{UH}_{3}$ pyrophoricity include the hydride content in the corrosion layer, the thickness of the accumulated corrosion layer, the specific area (average particle size), the oxidizing gas, the total heat load (due to decay, external heating and chemical reaction), and the heat dissipation. 
As with uranium metal, the specific surface area is the dominant factor in the combustion of $\mathrm{UH}_{3}$. Uranium hydride is comparable to the reactivity of uranium metal when the initial specific surface areas (or particle size distributions) for both materials are comparable. Uranium hydride characteristically forms a fine powder of high specific surface area. When produced by the gas-solid phase hydriding of uranium metal, the powder has a median diameter on the order of 10-20 microns and has a specific surface area on the order of $0.5 \mathrm{~m}^{2} / \mathrm{g}$. By comparison, the product from aqueous corrosion of uranium, which includes $\mathrm{UH}_{3}$, has a high specific surface area on the order of $30 \mathrm{~m}^{2} / \mathrm{g}^{6}$ Tyfield has reported the following particle size distribution for the product from aqueous corrosion of metal fuel: $:^{39}$

$\begin{array}{ll}\text { diameter }>8 \mu \mathrm{m} & 75 \mathrm{wt} \%, \\ \text { diameter }=5-8 \mu \mathrm{m} & 7.5 \mathrm{wt} \%, \text { and } \\ \text { diameter }=0.4-5 \mu \mathrm{m} & 17.5 \mathrm{wt} \% .\end{array}$

When converted from a wt\% to a particle count distribution, the median particle size is on the order of 1 to 2 microns. This size is consistent with hydride film thicknesses of $\approx 2 \mu \mathrm{m}$ at the corrosion interface as reported by Tyfield. ${ }^{39}$ These data indicate a relatively small particle size and a high particle surface area or porosity for $\mathrm{UH}_{3}$ produced by corrosion of the metal, which can depress the ignition temperatures dramatically. In fact, fine powders of uranium metal, prepared by thermal decomposition of synthetic $\mathrm{UH}_{3}$ with a mean particle size of $2.4 \mu \mathrm{m}$, ignited at $125^{\circ} \mathrm{C}$, or more than $100^{\circ} \mathrm{C}$ lower than the ignition temperature expected simply on the basis of particle size alone. The extraordinarily low ignition temperature was due to the high degree of surface roughness or porosity of the particles. ${ }^{47}$ Therefore, if present in concentrations sufficient to cause local heating, the fine $\mathrm{UH}_{3}$ produced by corrosion can serve as the 'match head' for ignition of the bulk metal at ambient or moderate temperatures.

There are no quantitative data from concerted testing for gaging the ignition potential of residual hydride in corroded fuel. However, Waber reported the corrosion of $2 \mathrm{wt} \% \mathrm{Mo}$ fuel for approximately 1 year in water vapor $\left(50 \%\right.$ relative humidity at $\left.75^{\circ} \mathrm{C}\right)$. His data indicated a weight gain equivalent to the accumulation of $0.75 \mathrm{~mm}$ layer of corrosion product, with at least $0.7 \%$ residual $\mathrm{UH}_{3}$ at the interface. The mass of corrosion product and hydride is comparable to the 1-year entry in Table 5. Waber reported that the corroded material, when exposed to air, "became quite warm (estimated $75-100^{\circ} \mathrm{C}$ ), but did not ignite"? In a separate study, 0.35 atomic $\% \mathrm{H}_{2}$ in clean pure uranium metal, present as $\mathrm{UH}_{3}$, did not cause ignition nor influence the uranium ignition characteristics of the instrumented metal sample in any way. ${ }^{47,48}$

The above discussion indicates that the hydride can ignite at moderate temperatures if it has sufficiently high surface area, but can ignite the bulk metal only if the localized heat output from hydride combustion, and therefore the localized mass of hydride, is above some threshold value. The above data indicate that a $1 \%$ hydride concentration may have sufficient localized mass and can oxidize rapidly enough to generate measurable heat. Such heating will only be a problem if metal fuel is highly sensitized to ignition by its condition and configuration (depressed ignition temperature), or by high fuel temperature due to decay heat or external heating. 


\section{Ignition Model}

Ignition theories that include heat load and heat dissipation factors have been developed by and used in the chemical industry, and have been applied to the nuclear industry. The ignition aspect of the pyrophoricity problem has been analyzed for Westinghouse Hanford Company, and has resulted in the recent development of an ignition theory model for uranium metal (and hydride) pyrophoricity. ${ }^{51}$ The model includes such considerations as the $\mathrm{UH}_{3}$ content in the corrosion layers, the depth of the corrosion layer, the particle size of the hydride, the total gas pressure above the layer, and the oxygen partial pressure in the gas.

Calculations of ignition temperatures for uranium and uranium hydride powder layers have been supplied by Martin Plys of Fauske Associates, Inc. as a function of a number of factors. ${ }^{52}$ These factors were: $\mathrm{UH}_{3}$ mass fraction $\left(100 \%, 10 \%\right.$, and $2 \% \mathrm{UH}_{3}$, with the balance being $\left.\mathrm{UO}_{2}\right)$; an average particle diameter of 1,2,3.3, 10 and 33 microns; powder layer depth of 1,2,3, and $4 \mathrm{~mm}$; and conductivity of the overlying gas (expressed as steam partial pressures of $0,1000,2000$, and $3000 \mathrm{~Pa}$ ). A conservative decay power of $10,000 \mathrm{~W} / \mathrm{m}^{3}$ and a powder packing fraction of 0.4 were assumed for these simulations. The results of these calculations indicate that for a corrosion layer $1 \mathrm{~mm}$ thick, containing $2 \% \mathrm{UH}_{3}$ of particle diameter $2 \mu \mathrm{m}$, and a partial water vapor pressure of $3000 \mathrm{~Pa}$, the ambient gas (air) temperature must be greater than $120^{\circ} \mathrm{C}$ to cause ignition of the $\mathrm{UH}_{3}$. The threshold ambient gas temperature drops as the powder layer depth increases, the particle size decreases (and the specific surface area increases), and the $\mathrm{UH}_{3}$ content increases. ${ }^{52}$ These results are summarized graphically in Figure 1. The results were calculated for an air environment, and assumed that the oxide layer was transparent to the diffusion of air.

As shown by the projections of the ignition model in Figure 1, the corrosion layer characteristics given in Table 5 are insufficient to cause spontaneous ignition of the hydride unless the fuel or air temperature were above $120^{\circ} \mathrm{C}$. The residual hydride will oxidize, causing some degree of selfheating of the fuel. These levels of hydride are unlikely to cause ignition of the bulk uranium metal at room temperatures, even if sensitized by the swelling or fission product content. However if the bulk metal is being actively heated to temperatures above $150-200^{\circ} \mathrm{C}$, the oxidation of the hydride might contribute to the onset of self-heating combustion of the bulk uranium, and possibly ignition.

\section{Consequence of Corrosion on the Pyrophoricity of Uranium Metal or Alloy Fuels}

Although the dissolved oxygen content is not measured for storage basin waters, we can assume that the basin waters have near saturation levels of dissolved oxygen, since the CPP-603 and CPP-666 basins are open-air basins, have active circulation for purification of the basin water, and have a low biological oxygen demand. Except for those instances where the spent fuel is stored wet in containers that restrict water exchange, the oxygen levels are most likely sufficient to minimize the rate of corrosion of the uranium metal. The spent fuels described in Table 1 have been stored bare or contained in an open-topped can in oxygenated water. 
Figure 1. Ignition temperatures of $2 \% \mathrm{UH} 3$ in corrosion product as a function of layer depth, particle size, and water vapor pressure.

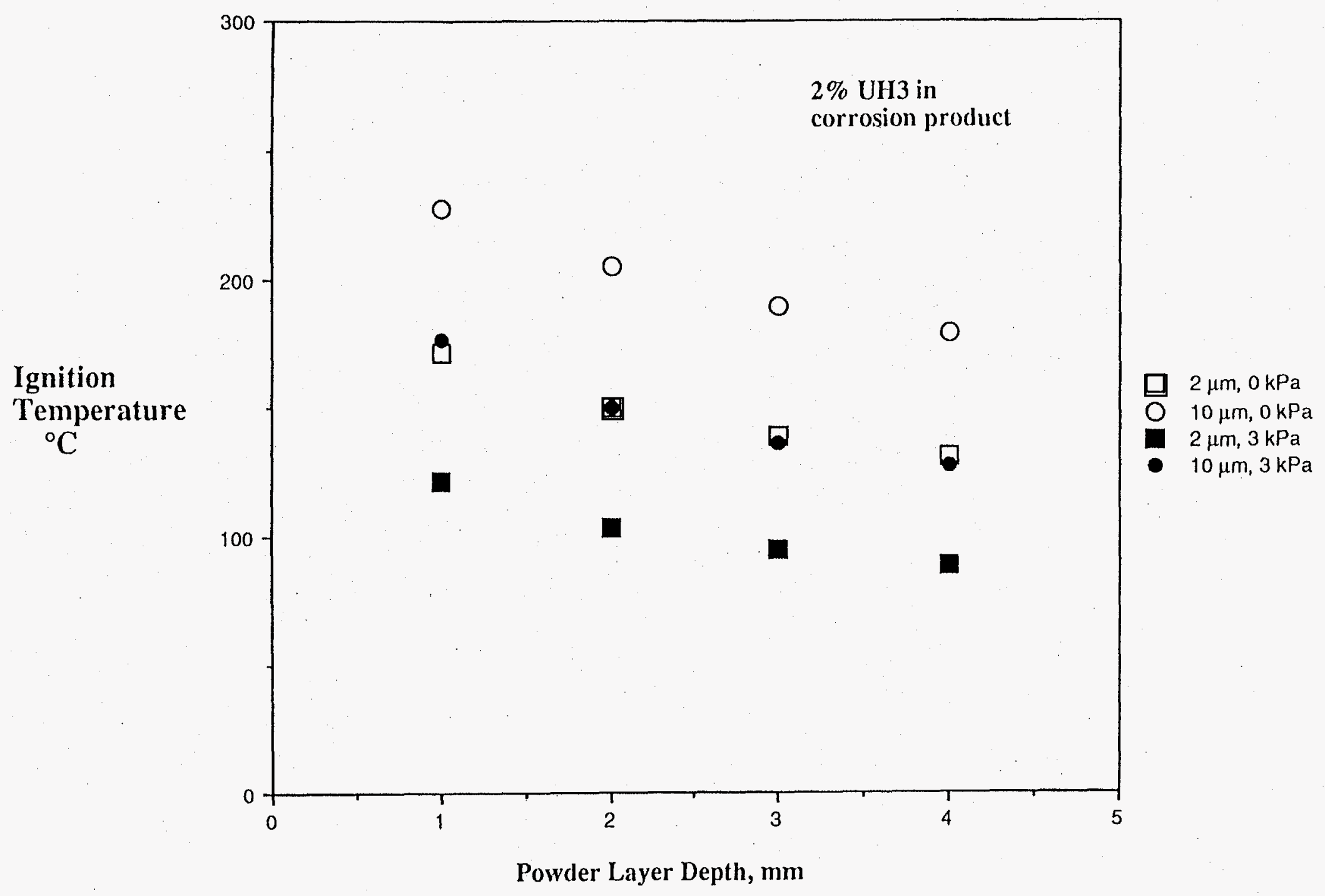


For uranium metal fuels, the extent of corrosion can be calculated from the rate expressions for immersion as listed in Table 2 (or taken from Table 5). The corrosion rates must be modified for specific fuel or storage conditions, including the extent of fuel swelling, alloy or impurity effects, oxygenated or de-oxygenated storage conditions, $\mathrm{pH}$ conditions, and galvanic effects.

Such calculations must be corroborated by remote video inspections of the corrosion layers on the fuels whenever possible to ensure that unknown circumstances have not affected the fuel. One obvious consideration is the determination of the thickness of the corrosion layer. For long storage times or accelerated corrosion conditions, calculations may indicate the formation of thick corrosion layers. In reality, accumulations of corrosion product beyond several millimeter thicknesses are not likely unless restrained by cladding, coatings, or the fuel assembly structure. Uranium oxidation characteristically maintains a tightly adherent $\mathrm{UO}_{2}$ layer with a steady-state thickness of only 1 to $3 \mu \mathrm{m} .{ }^{24}$ Internal stresses cause the spallation of material beyond that thickness and reduce the remaining corrosion product to a porous, layered mass that can readily slough from the surface. Conversely, configurations that support the loose oxide films may lead to thick accumulations of corrosion product. Furthermore, configurations that promote the hydrogen entrapment, slow water and oxygen transfer, and shifts in $\mathrm{pH}$ may accelerate corrosion (crevice corrosion) and optimize hydride formation.

For uranium metal fuels minimally affected by irradiation, the corrosion layer even for the oldest fuels in the basin would be less than $1 \mathrm{~mm}$ thick. Furthermore, extrapolations using equations 17 or 19 indicate that the hydride content resulting from corrosion will be at low levels, below $1 \% \mathrm{UH}_{3}$ as shown in Table 5. The combination of sub-millimeter thicknesses of accumulated corrosion product and sub-percentage levels of $\mathrm{UH}_{3}$ result in an ambient gas temperature threshold $>120^{\circ} \mathrm{C}$ for ignition as shown in Figure 1. Therefore, while the hydride will oxidize and may release considerable heat upon exposure to air, the hydride is not likely to ignite unless the fuel or its surroundings were at $>100^{\circ} \mathrm{C} .{ }^{52,53}$ Likewise, even if we assume that the self-heating combustion threshold for the bulk metal were $250^{\circ} \mathrm{C}$, it is not likely that the metal will be heated enough to phase into self-heating combustion and ignition. These conclusions are in line with complex-wide experience, in which the only reported incidents of spontaneous combustion or ignition of fuel were associated with fuel stored wet for less than 5 years. ${ }^{4}$

Because of their unique characteristics, the BMI-SPEC and the aluminum plate fuels are not entirely consistent with the above summary, and require some elaboration.

\section{BMI-SPEC}

The BMI-SPEC fuel plates are not likely to present any risks of pyrophoricity upon retrieval or drying. On the basis of the long storage time and the accelerated corrosion due to its composition, we expect that most of the fuel has corroded to the oxide and contains very low levels of residual hydride. Moreover, the ignition temperature of any remaining metal (if any) should be high in view of the alloy composition and the lack of irradiation swelling (low burnup). However, we cannot categorically and unequivocally exclude the possibility of pyrophoricity because of substantial 
uncertainties concerning the post-irradiation history, the storage configuration, and the current actual condition of the spent fuel.

The BMI-SPEC fuel consists of three experimental fuel plates that were placed in basin storage 35 years ago. Records indicate that some of the cladding on the fuel melted in the irradiation experiments, exposing as much as $20 \%$ of the uranium surface. ${ }^{54}$ At the very least, the cladding was breached at two places on each of the three plates by the destructive sampling for metallography during post-irradiation examination (PIE). Because of apparent inconsistencies in the documentation, we are not certain whether the fuel has been immersed in water since its receipt, or whether it was initially canned hermetically but was later exposed to water due to corrosion of the can. For this discussion we will assume that the fuel has been exposed to water since its receipt.

Videotapes presently on file do not show any images of the individual BMI-SPEC fuel plates or give any information from which to infer the condition of the fuel. However, reference 16 summarized the condition of the BMI-SPEC plates as being dark gray in appearance and apparently free of visible corrosion. This summary has several possible implications concerning the fuel condition:

- The fuel plates may have been declad as part of the PIE processing, and the exposed uranium surfaces may have corroded to a dark gray/black corrosion film.

- The original aluminum cladding has completely corroded and sloughed away, exposing the surface of the fuel meat to corrosion.

- The original test irradiation resulted in considerable melting of the thick ribbed cladding, exposing the thin nickel coating and possibly the uranium metal fuel meat; the exposed surfaces of the fuel meat may have corroded to a dark gray/black corrosion film.

- Except for the damage from PIE sampling, the aluminum cladding is relatively intact and protected by the postulated carbonaceous layer. In this case, corrosion would have initiated primarily at the cladding breaches caused by the destructive PIE sampling.

If large areas of the fuel meat had been exposed by stripping, corrosion or melting of the cladding, then most if not all of the fuel meat will have corroded away after 35 years of water storage. The stress-induced corrosion peculiar to U-Mo alloys may have increased corrosion rates by more than a factor of ten. Because of the long exposure to water, the residual uranium hydride would be present at sub-percentage levels in the corrosion product. In this condition, it is highly unlikely that the BMI-SPEC fuel plates pose a risk of spontaneous ignition and uncontrolled combustion. Furthermore, in this scenario, very little metal will remain to pose a threat of ignition. The greatest threat of combustion may come from the accumulated layer of corrosion product at the bottom of the can.

The uniform gray appearance of the fuel, with no gross evidence of corrosion, might be ascribed the complete corrosion and sloughing of the aluminum cladding and exposure of the fuel meat. However, this possibility does not seem realistic. Since the minimum thickness of the ribbed $\mathrm{Al}$ cladding was 0.035 inches $(0.90 \mathrm{~mm})$, complete reaction and sloughing of the cladding is not likely. General corrosion of Al would thin the cladding by only 0.005 inches in 35 years, unless accelerated by a galvanic couple or non-neutral $\mathrm{pH}$ conditions. Pitting corrosion would be too localized to strip the ribbed $\mathrm{Al}$ cladding unless aided by mechanical action. If the cladding was indeed rapidly 
stripped by such conditions, the extent of the stress-induced accelerated corrosion would be difficult to gage since we do not know the duration of exposure nor the actual rate of corrosion. However, the hydride content is still expected to be at sub-percentage levels and of no real risk of ignition. Furthermore, the metal itself is not expected to be susceptible to spontaneous ignition at low temperatures, since swelling-induced sensitization should be minimal and compensated by the molybdenum composition.

If the aluminum cladding is still in place, two conditions may exist: disrupted or distended cladding with extensive corrosion of the fuel meat ; or robust intact cladding, with internal crevice or 'blind pocket' corrosion of the fuel meat in the vicinity of the PIE damage sites. Because of the stressinduced accelerated rate of corrosion of low-alloy U-Mo alloys, the fuel plates should show extensive corrosion after 35 years exposure. If the cladding had been ruptured by the volume expansion of the corrosion product, the increased surface area of exposed fuel meat will have resulted in unhindered, extensive corrosion. It is highly likely that most of the fuel meat would have been attacked and disintegrated, especially since the corrosion rate is not limited by a restricted surface area or restricted influx of water. The anoxic corrosion conditions within the plate structure, in conjunction with the stress cracking disintegration of the fuel meat, would vastly increase the corrosion rate.

The worst scenario is that in which the cladding was robust enough to have resisted splitting or massive distension by the expanded corrosion product. In this scenario, the extent of the corrosion might be limited to an area of several centimeters radius around the PIE damage sites. Unfortunately, the 'blind pocket' corrosion configuration can trap much of the hydrogen that is produced by the corrosion reaction and can maximize the formation and accumulation of $\mathrm{UH}_{3}$ at the corrosion front. Depletion of the hydride is limited by the loss rate of the hydrogen, which in turn is impeded by the blind pocket configuration and the long diffusion path through the extensive accumulation of corrosion product.

In this scenario, the probability is high that a substantial amount of hydride has accumulated, large enough to ignite spontaneously or to self-heat to a red glow. Whether there is enough metal to ignite depends on the extent of metal corrosion. However, rough order of magnitude calculations indicate that if the cladding is robust enough to hold the corrosion product in place to form a 'plug', then diffusion of air to the hydride pocket will be sufficiently slow to limit the rate of oxidation to safe levels. In this case, the rates of heat generation by the oxidation and the heat loss by the fuel plates are sufficiently balanced to maintain low fuel temperatures and to prevent ignition of the metal. ${ }^{55}$

Unless special unforeseen crevice corrosion conditions prevailed, the corroded fuel is not pyrophoric. If we assume a 35-year corrosion period and unrestricted corrosion of the fuel plates, consistent with a scenario in which the fuel plates were declad or the cladding split open as corrosion progressed, then the residual hydride levels in the corrosion product should be at sub-percentage concentration levels and present little to no risk of pyrophoricity. On the other hand, if the corrosion conditions are such that high levels of hydride could have formed, as in the blind pocket corrosion 
scenario above, then potentially pyrophoric conditions might exist. However the risk of pyrophoricity will be substantially reduced or eliminated if the corrosion product forms a protective plug that severely impedes the rate of diffusion of air to the hydride.

Obviously, the BMI-SPEC fuel should be carefully examined prior to retrieval to evaluate the true extent of corrosion and the pyrophoricity risk. Without more definitive information, it would be prudent to assume that the condition of the fuel may present some risk of pyrophoricity. A careful video inspection prior to retrieval should resolve some of the uncertainties about the safety of the fuel. The extrusion of corrosion product from the PIE damage sites, or the distension or rupture of cladding, should be obvious in the video inspection and should permit a better assessment of the extent of corrosion and risk of pyrophoricity.

If a careful examination of the corroded BMI-SPEC fuel indicates a highly questionable condition or a high risk of pyrophoricity, it would be prudent to retrieve the fuel plates using a system purged with inert gas to ensure safe retrieval. The fuel must also be passivated prior to further processing. Passivation methods are discussed in the appendix.

\section{Uranium-Aluminide Plate Fuels}

The uranium aluminide fuel plates present no risk of spontaneous ignition and uncontrolled combustion in normal retrieval and handling conditions. In fact, there have been no reported incidents of fuel combustion or ignition in the various ATR fuel reprocessing campaigns at ICPP which involved handling of ATR fuels in air environments. Over-riding factors that differentiate and mitigate the potential pyrophoricity of corroded aluminum plate fuel from uranium metal plate fuels are the composition, the chemical reactivity, and the microstructure of the uranium aluminide fuel meat.

The composition of the aluminide fuel meat, nominally $\mathrm{UAl}_{3}$, dictates that at least three moles of pseudoböhmite $\left(\mathrm{AlO}(\mathrm{OH}) \cdot \mathrm{xH}_{2} \mathrm{O}\right)$, boehmite $(\mathrm{AlO}(\mathrm{OH}))$, or bayerite $\left(\mathrm{Al}\left(\mathrm{OH}_{3}\right)\right.$ form for every mole of $\mathrm{UO}_{2}$, and commensurately further dilute the residual $\mathrm{UH}_{3}$ that may have formed. In addition, the hydrated nature of the pseudoböhmite and bayerite that comprises the bulk of the corrosion product will facilitate the accelerated diffusion of water (as compared to a $\mathrm{UO}_{2}$ matrix), and the faster reaction of the $\mathrm{UH}_{3}$ dispersed in the corrosion product. Furthermore, the hydration of the pseudoböhmite and bayerite and the thermal decomposition of the bayerite represent heat sinks that help to dissipate the heat released by the hydride oxidation and to control the reaction.

The microstructure and the relative reactivities of the alloys in the composite fuel plates further mitigate the formation of significant accumulations of $\mathrm{UH}_{3}$. General corrosion of aluminum proceeds at a much slower rate in water of neutral $\mathrm{pH}$ than uranium metal. Therefore, for 10 years corrosion time, the extent of general thinning of the 0.010 inch thick cladding will be minimal (0.00013 inches). Unless high-pH conditions prevailed in the water trapped in the cooling channels of the assemblies, massive stripping of the cladding and exposure of the fuel meat will not occur.

Localized penetration by pitting corrosion is a concern. ${ }^{17,33,34,56}$. The cladding of several, if not all, of the fuel plates in each assembly is virtually certain to have been penetrated by pitting corrosion 
during the 10-year storage period in the basins. However,because the diameter of the corrosion pits penetration through the aluminum cladding is on the order of only 0.5 to $1 \mathrm{~mm}$, and because the fuel meat consists of a discontinuous dispersion of $\mathrm{UAl}_{\mathrm{x}}$ powder in a pressure-bonded aluminum matrix, only a small fraction of the total fuel meat is exposed to corrosion by each pitting penetration. Because the continuous aluminum matrix reacts considerably slower than the $\mathrm{UAl}_{\mathrm{x}}$ particles, propagation of the corrosion front is limited by the aluminum corrosion rate. Furthermore, the hydrogen gas that is produced by the corrosion reaction within the fuel meat layer is quite likely to slow the reaction by serving as a 'vapor lock', physically preventing the rapid intrusion of water into the fuel meat structure and disrupting continuous contact of liquid water at the reaction interface.

The higher intrinsic reactivity of the $\mathrm{UAl}_{\mathrm{x}}$ powder, and the higher surface area due to the porosity $(\approx 10 \%)$ of the composite and the irradiation-induced swelling, are expected to cause the rapid reaction of the fuel alloy before the surrounding $\mathrm{Al}$ matrix reacts significantly. Such conditions also favor the consumption of any $\mathrm{UH}_{3}$ that might have formed. Therefore, the reaction rate of the aluminum matrix will limit the propagation of the corrosion front and the accumulation of hydride within the fuel meat. In fact, several reports concerning the destructive evaluation of ATR fuel elements that failed in service have indicated that pitting penetration of the cladding has resulted in the preferential reaction of the fuel meat. ${ }^{17,28,33,34,37,38,56}$ Gamma-scan mapping and metallographic examination of the defective plates have defined a circular reaction front that was confined to the fuel meat and did not affect the cladding. ${ }^{34,56}$ Furthermore, the reaction front was well-defined within the aluminum matrix, indicating that the reaction of the $\mathrm{Al}$ matrix limited the progression of corrosion. The affected volume in the fuel meat zone was empty and completely devoid of corrosion product, indicating complete disgorgement of corrosion product during the course of the reaction. Several mechanisms have been postulated to explain the removal of the corrosion product:

- Physical 'sweeping' action caused by the high flow rates of reactor coolant.

- Alkaline dissolution of the aluminum, due to the locally high $\mathrm{pH}$ caused by dissolved fission products (cesium, rubidium).$^{57}$

- $\quad$ Physical disgorgement of solid products by the large volumes of gaseous fission products (krypton, xenon) that are released by the corrosion reaction..$^{s 5}$

- Physical disgorgement of solid products by the hydrogen gas generated by the corrosion reaction.

The complete absence of insoluble $\mathrm{UO}_{2}$ or fission product residues in the metallographic pictures and gamma-scans of the reaction voids suggests a physical disgorgement mechanism comparable to the last two mechanisms. If these mechanisms are indeed valid, they will further reduce any ignition risk from hydride.

\section{Conclusion}

The BMI-SPEC and the UAl $\mathrm{I}_{x}$ plate fuels stored in the CPP- 603 basin are unlikely to present any risk of pyrophoricity if maintained at temperatures less than $120^{\circ} \mathrm{C}$ during handling prior to drying and passivation. This conclusion has been based on a thorough evaluation of the available information on these fuels and the available literature pertaining to uranium metal, alloy and hydride corrosion and oxidation. 
The UAl ('aluminum plate') fuels present no risk of spontaneous ignition and uncontrolled combustion in normal retrieval and handling conditions. This conclusion is based on such factors as the protective microstructure of the fuel meat, the relatively low rate of corrosion for the aluminum matrix in the fuel, and the composition of the plate fuel, whose corrosion produces a preponderance of hydrated inert alumina products (pseudoboehmite, boehmite and bayerite). This conclusion is substantiated by the safety records of the various ATR fuel reprocessing campaigns at ICPP, in which the handling of ATR fuels in air environments has never resulted in incidents of fuel ignition.

In view of the long storage time, the accelerated corrosion of U-Mo alloys, the failure of the cladding during irradiation testing, and the breaching of the cladding during post-irradiation examination, the BMI-SPEC fuel meat has most likely corroded to the oxide and contains very low, safe levels of residual hydride. Moreover, the alloy composition and the lack of engineered porosity or irradiation swelling (low burnup) of the fuel impart substantial resistance to ignition. However, we cannot categorically and unequivocally exclude the possibility of pyrophoricity because of substantial uncertainties concerning the corrosion history and the current actual condition of the spent fuel.

The consequences of a pyrophoric event are severe enough to compel a conservative approach and contingency planning in retrieving the BMI-SPEC fuel from underwater storage. At the very least, the BMI-SPEC fuel handling unit should be re-examined carefully and thoroughly by remote video camera prior to retrieval, to determine unequivocally the extent of corrosion and the risks presented by the fuel. 


\section{APPENDIX}

\section{Passivation of $\mathrm{UH}_{3}$}

Even though we expect low levels of residual $\mathrm{UH}_{3}$ and negligible risk of uncontrolled pyrophoricity in the corroded plate fuels, the impact of a pyrophoric incident can be significant, both to schedules and to facilities, if we are not prepared to cope with such a possibility. An incident could generate enough heat to severely contaminate the facility. Therefore, we should plan on passivating any corroded fuels as part of the fuel conditioning process, or if necessary as part of the retrieval, to ensure beyond any doubt the safety of the process.

For retrieval of corroded fuels of questionable condition or high risk of ignition, the retrieval equipment should be purged with argon to prevent or extinguish uncontrolled combustion as the units are drained of water. As a fallback measure, if combustion becomes evident (e.g., such as a rising thermocouple temperature reading or evolution of water vapor) during the draining and drip-drying process, the fuel retrieval unit could be re-immersed to quench the combustion.

The spent fuel should be thoroughly dried under a flow of $\mathrm{Ar}-1 \% \mathrm{O}_{2}$ to oxidize completely any remaining $\mathrm{UH}_{3}$ and to minimize corrosion of the uranium metal and possible hydride formation during drying. The drying temperature should be increased steadily at a rate that ensures that water-saturated fuels do not rupture or disintegrate, and thereby suddenly expose a large mass of potentially active material. The maximum temperature should exceed $100^{\circ} \mathrm{C}$, and preferably reach $150^{\circ} \mathrm{C}$, both to ensure the complete reaction of the $\mathrm{UH}_{3}$ and to remove any residual water. Removal of residual water, including water produced by the passivation reaction, will minimize further formation of more $\mathrm{UH}_{3}$ during the drying process or during subsequent dry storage. Monitoring the water vapor levels in the exhaust gas stream from the drying process can serve as an indication of the completion of the drying and passivation process.

A more rigorous alternative passivation method is to heat the drip-dried fuel units to temperatures in excess of $300^{\circ} \mathrm{C}$ in a flow of inert gas. At such temperatures, the residual $\mathrm{UH}_{3}$ will dissociate at reasonable rates to uranium metal powder and free hydrogen. The metal powder thus formed is as pyrophoric as the original hydride, and must be passivated by controlled oxidation in an $\mathrm{Ar}-1 \% \mathrm{O}_{2}$ atmosphere to form $\mathrm{UO}_{2}$. Thermal dissociation and spallation ensures the complete passivation of the $\mathrm{UH}_{3}$, without forming residual water as a byproduct. However, the increased complexity of engineering and of operations may offset this advantage.

Moist or humid inert gas devoid of $\mathrm{O}_{2}$ is an ideal medium for hydride formation; most of the reported pyrophoricity incidents have involved storage of uranium metal in moist, oxygen-free conditions. Such conditions in storage of the retrieved fuel will result in further corrosion and $\mathrm{UH}_{3}$ formation, and will require careful passivation to avoid handling problems. Whenever possible, wet fuels with the potential for pyrophoricity should be processed in an environment with a low partial pressure of oxygen to passivate controllably any residual hydride that may be present, and to ensure that additional hydride does not form. Dry storage of these fuels must ensure a continuous supply of oxygen. 


\section{References}

1. K. M. Wendt, KMW-10-94, to Task Team Members, "Review of the CPP-603 South Basin Fuels Requiring Canning/Drying Task Team Meeting Held September 14", dated September 27, 1994.

2. Letter, Michael A. Simpson, BNFL Inc., to Donna Hale, INEL, dated June 2, 1994; attachment by Brian Hands.

3. D. Fisher and S. Knight, Decommissioning \& Waste Management B30 Bottled Fuel Opening Option Study, AEA-D\&W-0566, AEA Decommissioning \&Waste Management, Windscale, Seascale, Cumbria, CA20 1PF, April 1993.

4. Independent Technical Assessment Fuels Team, "N-Fuels Dry Storage Assessment", Richland, WA, June 22, 1994.

5. S. P. Henslee, J. R. Krsul, and D. B. Tracy to L. C. Walters, "Safety Issues Associated with the Handling, Shipping, and Storage of Uranium and U-10Zr", Argonne National Laboratory memo, May 27, 1988.

6. M. McD. Baker, L. N. Less, and S. Orman, Trans. Faraday Soc., 62, 2513 (1966).

7. J. T. Waber, 'The Corrosion Behavior of Plutonium and Uranium', Proceedings of the Second United Nations International Conference on the Peaceful Uses of Atomic Energy, Vol 6, Basic Metallurgy and Fabrication of Fuels, United Nations, Geneva, 1958, pp 204-214.

8. T. Kondo, E. D. Verink, F. H. Beck, and M. G. Fontana, Corrosion, 20, 314t (1964).

9. T. Kondo, F. H. Beck, and M. G. Fontana, Corrosion, 30(9), 330 (1974).

10. S. Orman, L. W. Owen, and G. Picton, Corrosion Science, 12, 35 (1972).

11. W. D. Wilkinson, Uranium Metallurgy, Volume II: Uranium Corrosion and Alloys, Interscience Publishers, John Wiley and Sons, 1962, Chapter 7. 
12. S. Zalkind, R. Eshkenazy, S. Harush, D. Halperin, D. Moreno, E. Abramov, and A. Venkert, J. Nuclear Mat., 209, 169 (1994).

13. D. H. Wood, S. A. Snowden, H. J. Howe, L. L. Thomas, D. W. Moon, H. R. Gregg, and P. E. Miller, J. Nuclear Mat., 209, 113 (1994).

14. Department of Energy Office of Nuclear Safety, Operating Experience Weekly Summary, Summary 92-24, October 2-8, 1992.

15. WINCO Lessons Learned Committee, ICPP Lessons Learned, Westinghouse Idaho Nuclear Company, August 11, 1994.

16. B. M. Palmer, Unclassified Fuels in the CPP-603 Fuel Storage Basins, WINCO-1215/UC510, Westinghouse Idaho Nuclear Company, Inc, The Idaho National Engineering Laboratory, March 1994.

17. S. P. Henslee, ATR Fuel Element Pitting, EG\&G Idaho Internal Report PR-T-80-030, April 1980.

18. L. G. Miller and J. M. Beeston, Extended Life Aluminide Fuel Final Report, EGG-2441, EG\&G Idaho, Idaho National Engineering Laboratory, June 1986.

19. ICPP Fuel Receipt Criteria, CPP-666.

20. M. J. Graber, G. W. Gibson, V. A. Walker, and W. C. Francis, Results of ATR Sample Fuel Plate Irradiation Experiment, IDO-16958, Phillips Petroleum Company, AEC Research and Development Report/ Metals, Ceramics and Materials, TID-4500 (26th Ed.), March 23, 1964.

21. V. A. Walker, M. J. Graber, and G. W. Gibson, ATR Fuel Materials Development Irradiation Results--Part II, IDO-17157, Phillips Petroleum Company, AEC Research and Development Report/Metals, Ceramics and Materials, TID-4500, June 1966.

22. A. G. Ritchie, J. Nuclear Mat., 102, 170 (1981). 
23. A. G. Ritchie, R. C. Greenwood, and S. J. Randles, J. Nuclear Mat., 139, 121 (1986).

24. C. A. Colmenares, "Oxidation Mechanisms and Catalytic Properties of the Actinides", Prog. Solid State Chem., vol. 15, Pergamon Press, Ltd, Great Britain, pp 257-364, 1984.

25. R. J. Pearce, M. J. Bennet, and J. B. Price, Nucl. Energy, 27 (5), 305 (1988).

26. W. D. Wilkinson, Uranium Metallurgv, Volume II: Uranium Corrosion and Allovs, Interscience Publishers, John Wiley and Sons, 1962, Chapter 8.

27. J. W. McWhirter and J. E. Draley, Aqueous Corrosion of Uranium and Alloys: Survev of Project Literature, ANL-4862, Metallurgy and Ceramics, Argonne National Laboratory, Chicago, Il, May 14, 1952.

28. K. Vinjamuri and R. R. Hobbins, Nuclear Technology, 62, 145 (1983).

29. W. E. Ruther and J. E. Draley, Corrosion of Al-U Alloys in High Temperature Water, ANL6054, Argonne National Laboratory, 1959.

30. H. B. Peacock and R. L. Frontroth, Properties of Aluminum-Uranium Alloys, WSRC-RP89-489/DE90 003889, Westinghouse Savannah River Company, Aiken SC., August 1989.

31. J. Draley and W. Ruther, Corrosion, 12, 441t (1956).

32. L. B. Lundberg, Corrosion of Spent ATR Fuel Elements Relative to Their Dry Storage, ERA-NRE-94-096, EG\&G Idaho, Inc., August 30, 1994.

33. K. Vinjamuri, Postirradiation Examination of Advanced Test Reactor Fuel Elements XA377N and XA379N, EGG-TFBP-5968, EG\&G Idaho, Inc., Idaho Falls, ID, September 1982.

34. S. L. Seiffert and A. H. Novick, Destructive Examination of Defective Fuel Plates From ATR Fuel Elements A197F and XA45@N, PR-T-79-016, EG\&G Idaho, Inc., Idaho Fall, ID, August 1979. 
35. G. W. Gibson, K. C. Sumpter, M. Zukor, and D. W. Knight, Examination of ATR Fuel Plates and Elements Made With Powdered $\mathrm{UAl}_{3}$ and Fabricated by Atomics International, CI1025, Idaho Nuclear Corporation, January 1967.

36. G. W. Gibson, The Development of Powdered Uranium-Aluminide Compounds for Use as Nuclear Reactor Fuels, IN-1133, Idaho Nuclear Corporation, Idaho Falls, ID, December 1967.

37. J. M. Beeston, R. R. Hobbins, G. W. Gibson, and W. C. Francis, Nuclear Technology, 49 , $136(1980)$.

38. W. Dienst, S. Nazare, and F. Thummler, J. Nuclear Mat, 64, 1 (1977).

39. S. P. Tyfield, Nucl. Energy, 27 (2), 91 (1988).

40. G. Fillmore, Lockheed Idaho Technologies Co., private communication.

41. G. C. Allen, P. M. Tucker, and R. A. Lewis, J. Chem. Soc. Faraday Trans. 2, 80,991 (1984).

42. K. Winer, C. A. Colmenares, R. L. Smith, and F. Wooten, Surface Science, 183, 67 (1987).

43. K. A. Winer, Initial Stages of Uranium Oxidation: A Surface Study, Ph.D. thesis, University of California-Davis, University Microfilms International, Ann Arbor, MI, 1985.

44. M. McD. Baker, L. N. Less, and S. Orman, Trans. Faraday Soc., 62, 2525 (1966).

45. J. H. Perry, C. H. Chilton, and S. D. Kirkpatrick, eds., Chemical Engineer's Handbook, Fourth Edition, McGraw-Hill Book Company, 1963, p 14-3.

46. R. C. Weast, ed., Handbook of Chemistry and Physics, 57th edition, CRC Press, Cleveland, $\mathrm{OH}, 1976, \mathrm{p} \mathrm{B}-138$.

47. J. G. Schnizlein, P. J. Pizzolato, J. A. Porte, J. D. Bingle, D. F. Fischer, L. W. Mishler, and R. C. Vogel, Ignition Behavior and Kinetics of Oxidation of the Reactor Materials, Uranium. 
Zirconium, Plutonium and Thorium, and Binary Alloys of Each, ANL-5974, TID-4500, 14th ed., Argonne National Laboratory, Lemont, IL, April 1959.

48. J. G. Schnizlein, L. Baker, Jr., and J. D. Bingle, J. Nuc. Materials, 20, 39 (1966).

49. M. J. Bennett and J. B. Price, J. Nuc. Materials, 101, 44 (1981).

50. R. H. Rossi, "The Environment Committee Report to the House of Commons, Session 19851986", Vol. III Appendices, HMSO 191.

51. Martin Plys (Fauske Associates, Inc., Burr Ridge, IL), FAI Ignition Theory, presented at the Technology Integration Technical Working Group Meeting, DOE Integrated Spent Nuclear Fuel Program, Richland, WA, October 19, 1994.

52. Martin Plys, Fauske Associates, Inc., Burr Ridge, IL, letter to M. A. Ebner, LITCO, dated October 25, 1994.

53. Martin Plys, private communication.

54. Preliminary Results of Irradiation of a Piqua OMR Type Element in the OMRE, NAA-SRMEMO 3402, Supplement II to Preliminary Safeguards Report for the Piqua Organic Moderated Reactor (NAA-SR-3100), Atomics International , ACRS-AI-Piqua, Dec 31, 1959.

55. R. J. Kirkham, Lockheed Idaho Technologies Company, private communication.

56. S. L. Seiffert, Destructive Examination of ATR Fuel Element XA029HK Which Failed During Operation, PR-T-79-020, EG\&G Idaho, Inc., September 1979

57. M. L. Croson, Lockheed Idaho Technologies Co., private communication. 